Article

\title{
Singing to Emmanuel: The Wall Paintings of Sant Miquel in Terrassa and the 6th Century Artistic Reception of Byzantium in the Western Mediterranean
}

\author{
Carles Sánchez Márquez ${ }^{1,2}$ \\ 1 Department of Art and Musicology, Autonomous University of Barcelona, 08193 Bellaterra, Barcelona, Spain; \\ carlos.sanchez.marquez@uab.cat \\ 2 Terrassa City Council, 08221 Terrassa, Spain; carles.sanchezmarquez@terrassa.cat
}

Received: 24 July 2019; Accepted: 13 September 2019; Published: 29 September 2019

check for updates

\begin{abstract}
Since the late 19th century the wall paintings of Sant Miquel in Terrassa have drawn attention due to their singularity. From the early studies of Josep Puig i Cadafalch (1867-1956) to the present, both the iconographic program and the chronology of the paintings have fueled controversy among scholars. In particular, chronological estimates range from the time of Early Christian Art to the Carolingian period. However, a recent technical study of the paintings seems to confirm an early date around the 6th century. This new data allows us to reassess the question in other terms and explore a new possible context for the paintings. First, it is very likely that the choice of iconographic topics was related to the debates on the Arian heresy that took place in Visigothic Spain during the 5th and 6th centuries. Secondly, the paintings of Sant Miquel should be reconsidered as a possible reception of a larger 6th-century pictorial tradition linked to the Eastern Mediterranean, which is used in a very particular way. However, thus far we ignore which were the means for this artistic transmission as well as the reasons which led the "doers" of Terrassa to select such a peculiar and unique repertoire of topics, motifs, and inscriptions. My paper addresses all these questions in order to propose a new Mediterranean framework for the making of this singular set of paintings.
\end{abstract}

Keywords: Terrassa; Sant Miquel; wall painting; Emmanuel; Byzantium; Egypt

\section{Introduction}

The Church of Sant Miquel de Terrassa forms part of the complex of the Ancient Episcopal See of Egara. It is composed of three churches, all of which present a pictorial decoration in their apses: Santa Maria (Saint Mary), Sant Miquel (Saint Michael), and Sant Pere (Saint Peter).

The latest archaeological studies undertaken as part of the Pla Director de les Esglésies de Sant Pere (Director's Plan for the Churches of Sant Pere) (1995-2009) have enabled us to place the date for the start of the building of this artistic ensemble at the time when the ancient Roman municipality of Egara was designated an Episcopal See (ca. 450-465). During the bishopric of Ireneus, construction began on a great complex for the Cathedral of Santa Maria, the funerary building of Sant Miquel, and the parish church of Sant Pere (Figures 1 and 2). 


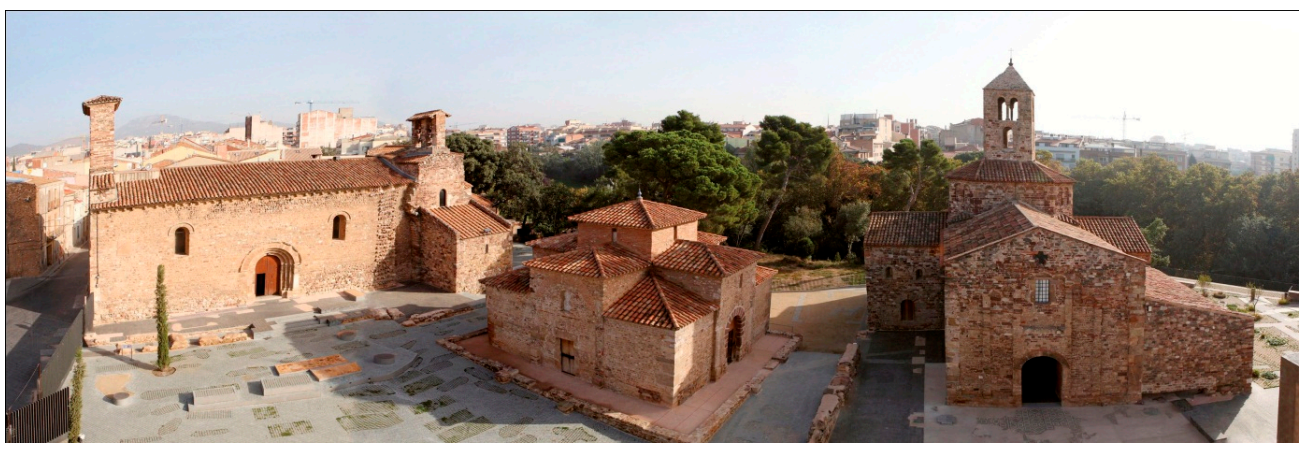

Figure 1. The Ancient Episcopal See of Egara. (c) Museu de Terrassa (with kind permission).

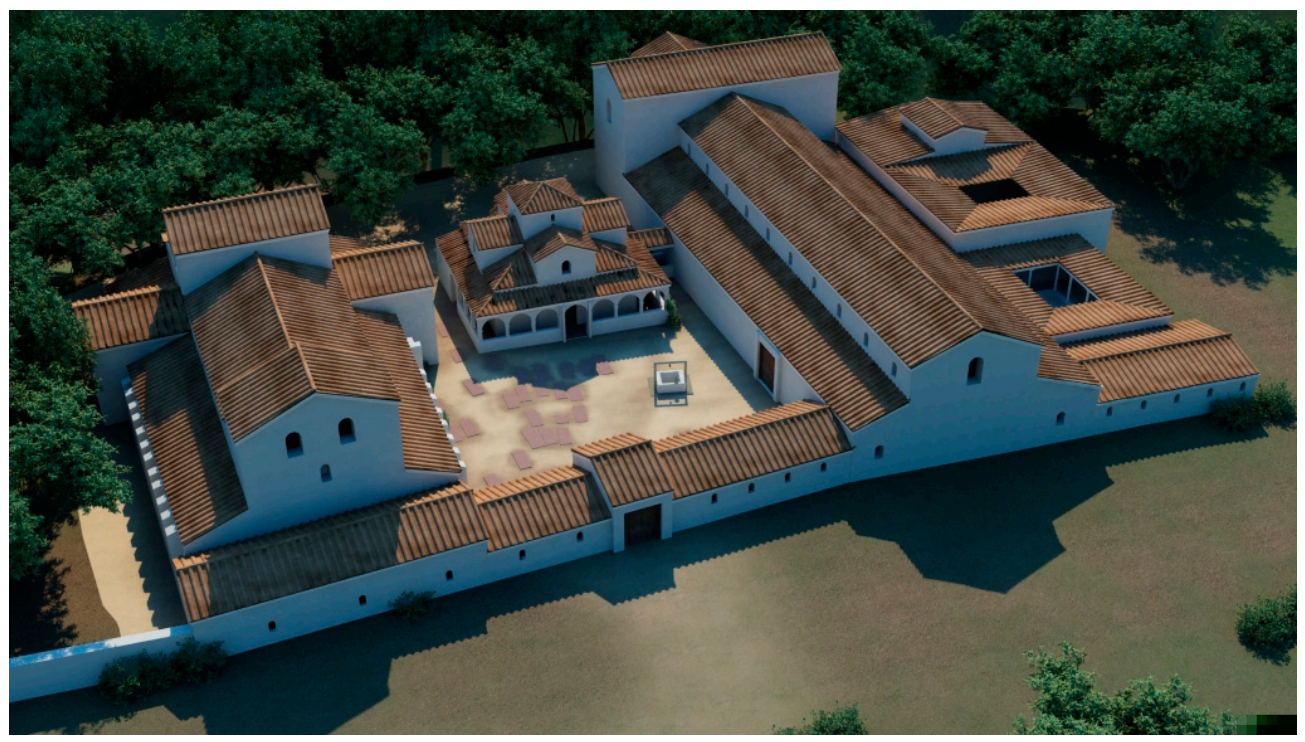

Figure 2. Episcopal See of Egara (Terrassa). Virtual reconstruction. (C) Dualmultimedia, according to G. Garcia, A. Moro, and F. Tuset (with kind permission).

Archaeological study has demonstrated that when the project for the Cathedral of Santa Maria was as yet unfinished, the original tripartite chancel of the building was transformed into a chancel consisting of a single apse, with a contained rectangular exterior and a semicircular interior. Archaeologists date this to the 6th century (Garcia Llinares et al. 2009). The building of this apse coincides with the completion of the construction project at the see of Egara, and by extension, with the construction of the actual Church of Sant Miquel. The main objective of this article is to show that the pictorial decoration of the apse of Sant Miquel is contemporary with the construction of the building (6th century).

Nonetheless, it is important to emphasize that the chronology of the paintings decorating the apses of the three churches has been the subject of debate. Following the discovery of the wall paintings, Puig i Cadafalch (1936, 1948, pp. 25-33) was the first scholar to carry out a minute analysis, in which he defended the stylistic (and therefore chronological) identities of the wall paintings of Sant Miquel and those of the Church of Santa Maria in the same episcopal complex:

The technique's identity, as well as some of the ornamental themes, compel us to believe that the two paintings [Santa Maria and Sant Miquel] should be considered to be contemporaries and perhaps to be the work of the same hand.

The author related the style and iconography of the paintings to those of Syria and Coptic Egypt, but also to the mosaics of Ravenna, which led to situating the pictorial ensemble of Santa Maria and Sant Miquel in the 6th century. Running counterpoint to the chronological hypothesis posed by Puig i Cadafalch and supported on one side by the historiography 
(Cirici i Pellicer 1945; Garcia Llinares et al. 2009; Ferran 2015), Josep Pijoan situated the paintings to be from the Carolingian Period (Pijoan and Gudiol 1948, p. 43).

In the wake of Pijoan, and based solely on iconographic and stylistic aspects, some authors who have studied the pictorial ensemble have proposed a later dates for the paintings;near the end of the 9th century (Ainaud de Lasarte 1959, 1976; Guardia 1992; Mancho 2012, 2018), circa the year 900 (Grabar 1945), in the 10th century (Barral i Altet 1981), and even at the end of the 10th and beginning of the 11th centuries (Cook and Gudiol 1950, p. 22).

It is well worth remembering that the last proposal for a later date (Mancho 2012, 2018) casts doubt on the technical and methodological data given for the different interventions, such that it is only based on a series of stylistic arguments defending the position that the paintings are from the time of Frodoí, Bishop of Barcelona (861-890), from the second half of the 9th century, when Egara had ceased to be an episcopal see.

Thus, since the studies of Puig i Cadafalch, the paintings of Sant Miquel have been the subject of a polarized historiographic debate between those who defend a Carolingian chronology (9th century) and those who situate them in the Late Antiquity. To this end, the interventions carried out on the ensemble in recent years by archaeologists, restorers, epigraphists, and art historians under the aegis of the Director's Plan for the Churches of Sant Pere have provided new data that leads us toward a later date-the 6th century.

In this context, this paper is divided into three parts: First, it outlines the creation of the Bishopric of Egara, the discovery of the paintings of Sant Miquel and its iconographic interpretation. Then, it looks into the historical and artistic framework of the paintings. Finally, the paper discusses about the chronology.

\section{The Creation of the Bishopric of Egara}

The founding of the Episcopal See of Egara dates back to the middle of the 5th century. At that time, Nundinarius, Bishop of Barcelona, decided to divide his diocese into two parts: the coastline (for the diocese of Barcelona) and the interior, where he created the new diocese of Egara, with Ireneus as its first bishop (Mundó i Marcet 1992, pp. 41-49; Martí i Bonet 1992; 2004, pp. 77-107; Ferran 2009, p. 59).

We know of the details of the foundation of the diocese of Egara thanks to the correspondence maintained between the Pope Hilarius (451-458) and Ascanius, Archbishop of Tarragona, with regard to the controversial appointment of Irineus (Bishop of Egara) as Bishop of Barcelona in the year 465. ${ }^{1}$ After the celebration of the Council of Santa Maria Maggiore of Rome, Pope Hilarius sent a letter to the Archbishop of Tarragona (30 December 465) which showed his disapproval of the bishops of Tarragona due to the appointment of Irineus as Bishop of Barcelona and ordered his immediate return to the See of Egara, which had been created only a few years earlier. These documents lead one to think, therefore, that the terminus ante quem for the founding of the bishopric would be the year 465 .

The granting of the Episcopal category to the old municipium flavium of Egara favored the formation of a grand construction campaign, beginning during the times of Irineus and ending the following century. The new project conceived the building of a grand episcopal complex organized into three terraces (Garcia Llinares et al. 2009). On the first terrace, located to the south, new offices and spaces designed for the episcopal residence were built, as well as a private chapel dedicated to Saints Just and Pastor. On the second terrace, the Cathedral of Santa Maria was built, with two distinct areas: the baptistery and the basilica itself. To the north of the cathedral, the funerary Church of Sant Miquel (Figures 3 and 4) can be found. Finally, on the third terrace, to the north, the parish Church of Sant Pere was built. In the western sector, and closing out the complex, a double funerary corridor was raised

1 The minutes of the Council of Santa Maria Maggiore, the letters of the bishops of Tarragona and the response from Pope Hilarius are found in the Collectio Canonum Hispania from the 7th century, the work of Saint Isidoro in the year 634. See (Migne 1844-1855, pl. 58, col. 12-20; 67, col. 315-20). 
to connect the baptistery with the parish church, such that all of the buildings were connected by a central garden that functioned as a cemetery. Today, important vestiges of the episcopal buildings are still preserved: the apse of the Cathedral of Santa Maria and the baptistery; the entirety of the building of Sant Miquel; and the apse of the parish Church of Sant Pere (Figure 5).

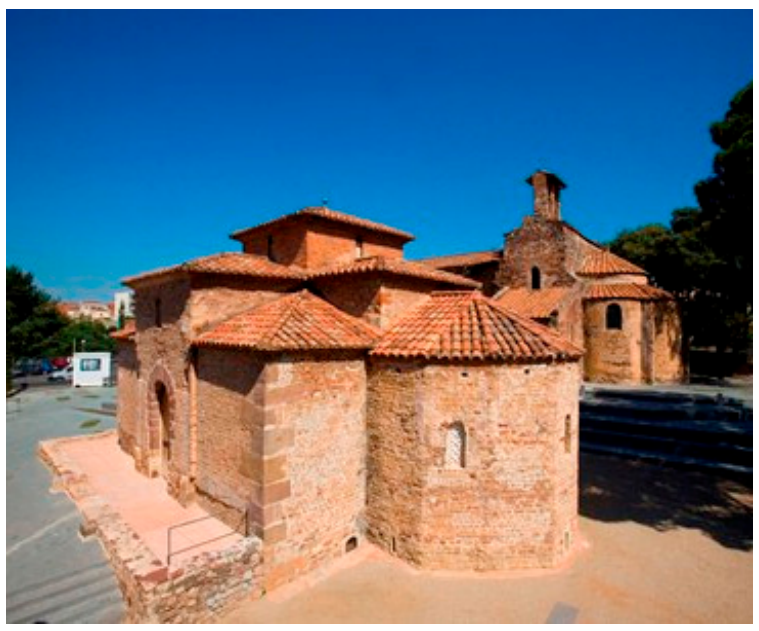

Figure 3. Church of Sant Miquel (Terrassa). (C) Teresa Llordés (with kind permission).

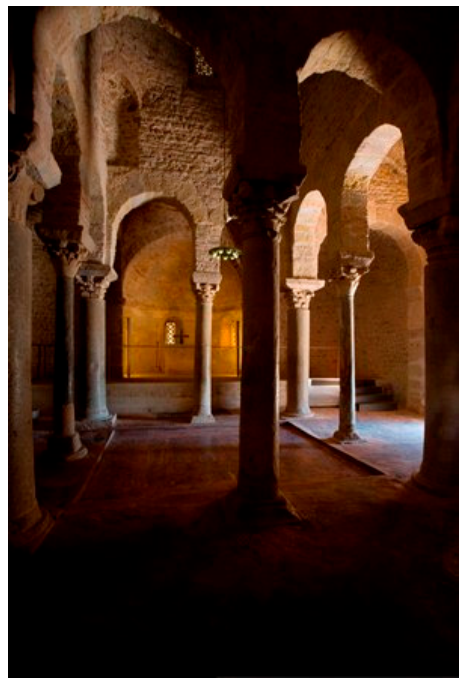

Figure 4. Church of Sant Miquel (Terrassa). (C) Teresa Llordés (with kind permission).

The Muslim invasions of the Iberian Peninsula would mark the end of the golden age of glory of the monumental complex and the end of the Bishopric of Egara. After the conquest of Barcelona in the year 801 by the Franks, the country's stability allowed for certain episcopal sees to be reinstituted (Soler i Jimenez 2003, pp. 90-81), with the exception of Egara and Empúries.

In the 12th century, the complex was the subject of a new building campaign. On 2 January 1112, the new Romanesque Church of Santa Maria was consecrated, reintegrating the apse of the ancient Episcopal cathedral, with its wall paintings. In the same way, toward the end of the 12th century, a new Romanesque nave was built at Sant Pere in the same complex, which was fit into the ancient trefoil apse of the Episcopal phase. 


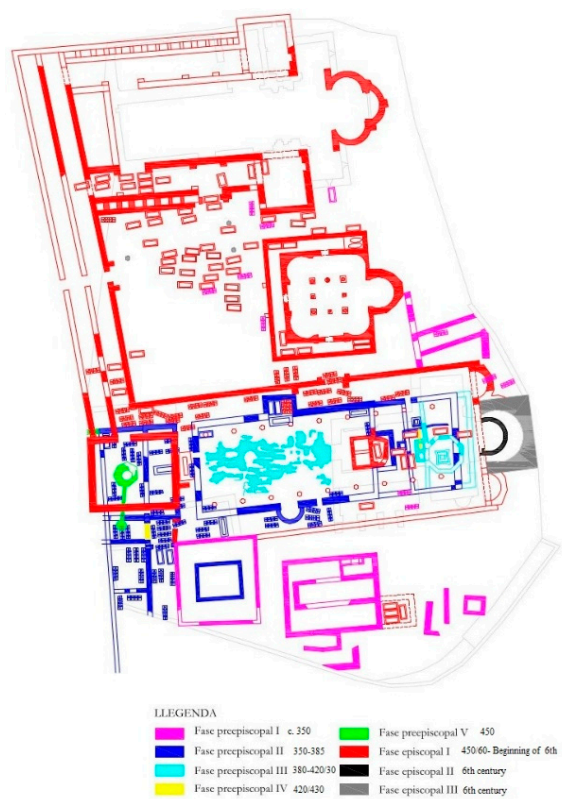

Figure 5. Architectural phases of the complex of Terrassa. According to G. Garcia, A. Moro, and F. Tuset. (C) G.Garcia, A. Moro and F. Tuset (with kind permission).

\section{The Recovery of a Forgotten Beauty: Discovery and First Studies of the Paintings}

The existence of the wall paintings of Sant Miquel de Terrassa has been known since the late 19th century. On 25 December 1892, the weekly magazine Ègara published an article entitled "Scientific and Artistic Movement in Terrassa", echoing the presence of pictorial remnants in the apse of the church. ${ }^{2}$ As can be observed in a photograph from the year 1878, the paintings were found hidden under a layer of lime that covered the entire apse. It was presided over by a Gothic altarpiece depicting Saint Michael, created by the painters Jaume Cirera and Guillem Talarn in the year 1450 (Figure 6).

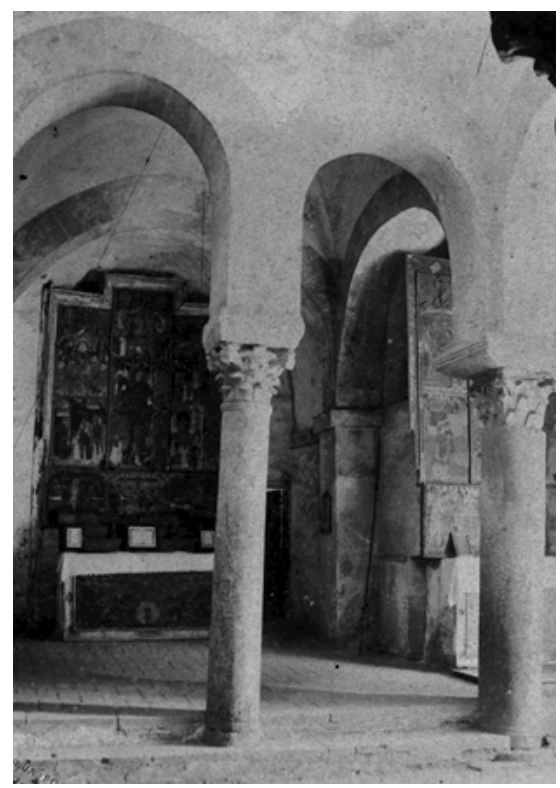

Figure 6. Inside of the church of Sant Miquel, c. 1878. Author: Adrià Torrija. (C) Museu de Terrassa, MdT 18955. 
Despite the fact that the pictorial decoration was known to exist since the end of the 19th century, it was not until the 1920's that the first intervention was undertaken to restore its memory. During the years 1927 and 1928, the paintings were restored as part of the restorative work at Sant Miquel, directed by architect and historian Josep Puig i Cadafalch (Castellano i Tresserra et al. 1993). At this moment, all of the building's interior facing was re-surfaced and the paintings were subjected to their first restoration, financed by Lluís Plandiura, consisting of the pictorial reintegration of the figures that could be seen beneath the layers of lime that had been removed.

The area of the apse located under the window line was also re-surfaced and covered with a new plaster layer for the definitive presentation of the restoration of the building by Puig i Cadafalch in 1929 and 1930. Consequently, if the lower area of the apse was also decorated with wall paintings, these were lost after the elimination of the plaster as part of the first intervention.

After the restoration, the pictorial cycle attracted the attention of the scholars, who undertook the first analysis of the ensemble. As well as the first study was undertaken by local historian Josep Soler i Palet (Soler i Palet 1928, p. 119), researchers such as Charles Kuhn pointed out the extraordinary discovery (Kuhn 1930, pp. 9-11). After these first analyses, Josep Puig i Cadafalch published his first contribution, entitled Les pintures del segle VI de la catedral de Égara, Terrassa (The 6th Century Paintings of the Cathedral of Égara, Terrassa), in which the Catalan historian presented a chronological hypothesis which he would maintain during his entire career (Puig i Cadafalch 1936, 1931, 1932a, 1932b). His article is of great importance, as not only does it include the first photographs of Sant Miquel, but Puig i Cadafalch also published the first tracings of its pictorial decoration, which are currently preserved in the archives of the Local Architectural Heritage Service of the Regional Council of Barcelona.

Since the 1950's, the paintings of Sant Miquel have been the subject of new studies (Grabar 1945; Pijoan and Gudiol 1948). The most distinguished among them were undertaken most recently by Guardia (1992), Mancho (2012, 2018), and Ferran (2015).

In the years 2001 and 2002 the paintings were the subject of important work in restoration undertaken by the ARCOR company as part of two campaigns: the first during the months of July and August of 2002, and the second between the end of 2001 and the first semester of 2002. ${ }^{3}$ The work consisted of consolidating the mortars, eliminating inadequate rehabilitation, the treatment of cracks and fissures, cleaning and a minimum of pictorial reintegration. The restoration not only allowed for the consolidation of the paintings but also allowed for the discovery of certain areas of these same paintings that were totally unknown, an important fact to advance in the knowledge of their iconography.

\section{Art, Music, and Liturgy at Sant Miquel}

Before entering into the iconographic and interpretive debate of the paintings of Sant Miquel, it would be worth carrying out a preliminary descriptive examination of their represented motifs. The decoration of the apse is organized into two registers, separated by two wide red-colored bands (Figures 7 and 8). The upper area presents a grand mandorla held by four angels, featuring the image of enthroned Christ inside, in which he holds a book with the remnants of an illegible inscription in his left hand. He is shown haloed, with a cross decorated by lines inside it and with three arms, among which the inscription $E M A / V V[\ldots]$ can be read, which should be translated as Em(m)anu(el) (Figure 9). As part of the restoration undertaken in 2001 and 2002, images of the Sun and Moon, cosmic symbols of eternity, were discovered on both sides of the mandorla. It is a very simple representation of two radial circles: the one situated to the left was identified as the Sun, while a similar one was on the right, but featuring a human face. This latter image still has the vestiges of a rectangular cartouche with an inscription LUNA (MOON) (Figure 10). ${ }^{4}$

3 See (ARCOR 2001, 2002). Information preserved in the archive of the Museum of Terrassa.

4 In pagan monuments, the Sun was represented as a radiated disc, or in Syria as a rosette with outspread petals, or as a cross limited by points. The Moon, for its part, appears represented as a rosette in the form of a helix or in its crescent shape, 


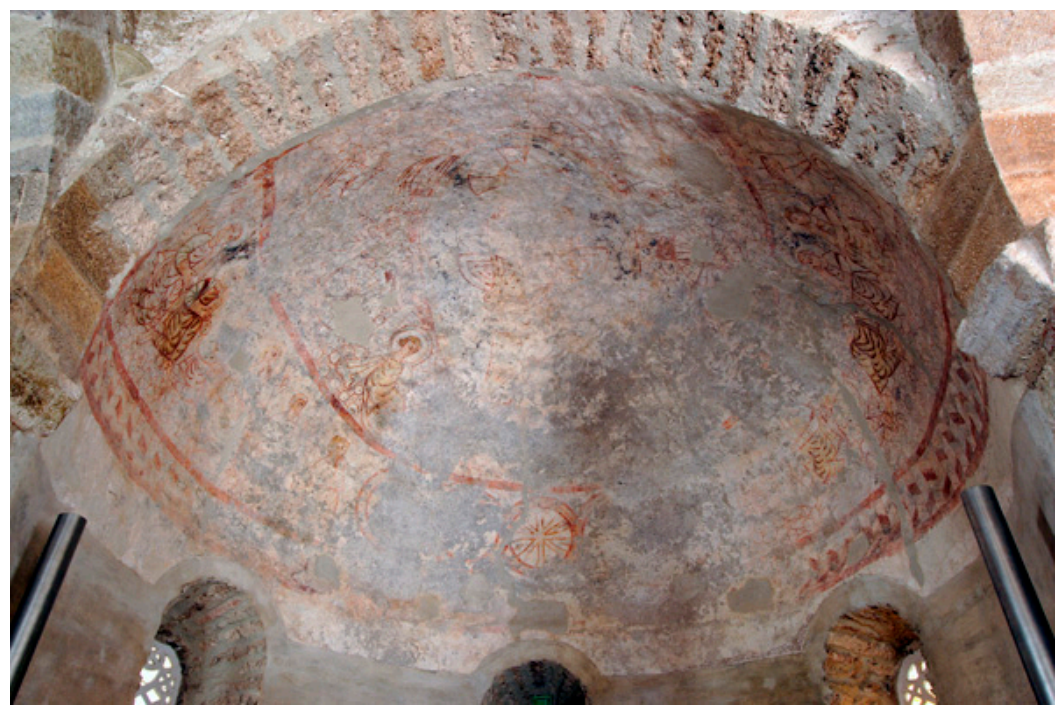

Figure 7. Sant Miquel de Terrassa, wall paintings of the apse. (C) author.

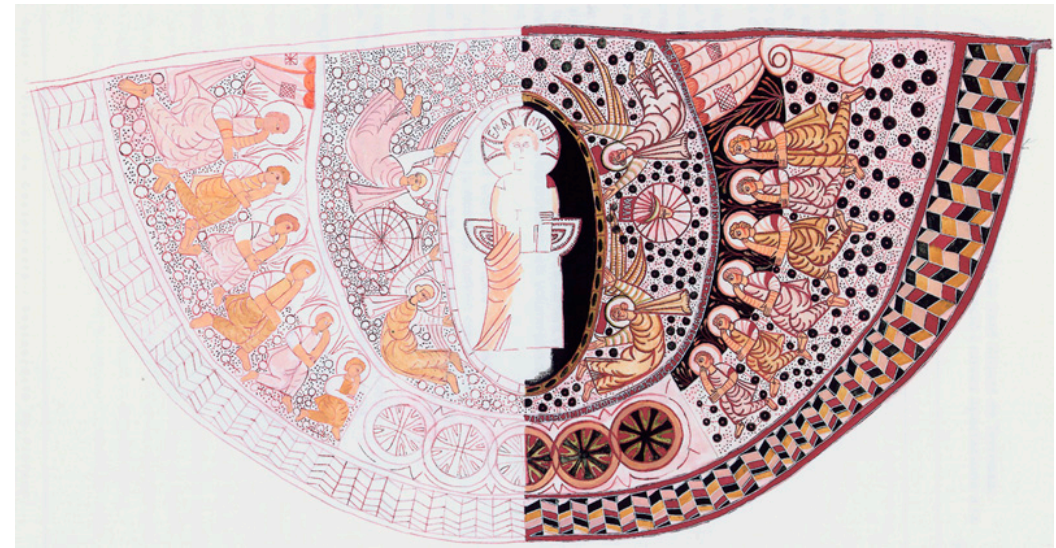

Figure 8. Drawing of the wall paintings of Sant Miquel (Terrassa). (C) ARCOR (with kind permission).

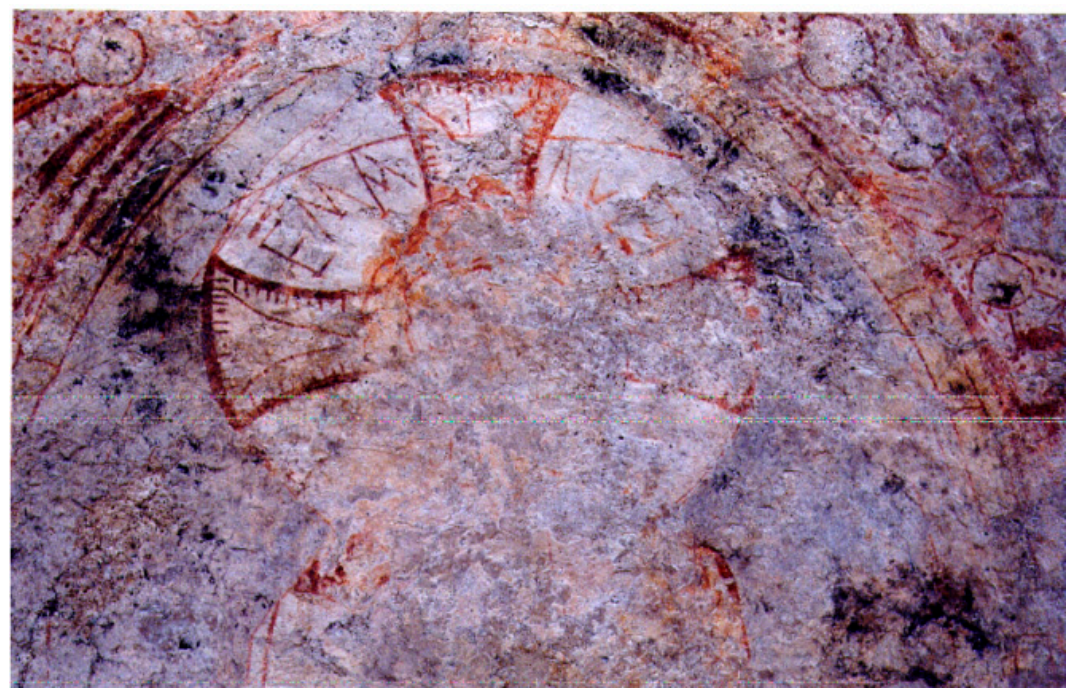

Figure 9. Sant Miquel de Terrassa, wall paintings. Inscription Em(m)anu(el). (C) ARCOR.

at times alone and at other times inscribed in a circle. These representational forms were quickly adopted by Christian artists, and we have preserved good examples of them in the Rabbula Gospels (6th century). 


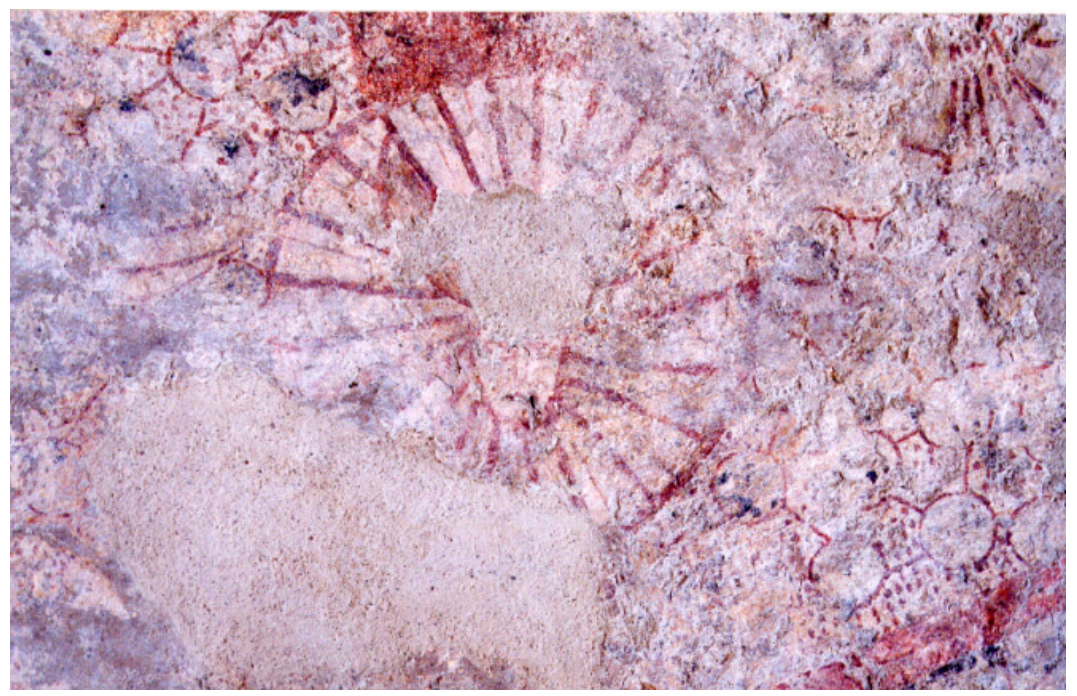

Figure 10. Sant Miquel de Terrassa, wall paintings. Image of the moon. (C) ARCOR.

The lower area is occupied by the apostles presented in profile, kneeling and wearing clothing that is clearly of a Roman tradition: a tunic, a praetexta toga, and sandals. In the central dividing band several tituli with the names of six apostles appear: Petrus, Andreas, Iacobus, Iohannes, Philippus, and Bartholomeus (Peter, Andrew, James, John, Philip, and Bartholomew). In the central part of this band, coinciding with the five circles of the lower register, there are lines that correspond to decorative motifs and next, there is another large band that would hold the inscriptions of six more apostles, which have disappeared. In the extreme right, we can only identify an "S", followed by a cross which we should relate to Paulus (the Apostle Paul).

Finally, in the space located between the two groups of apostles, five circles with concentric lines are represented. The central one has eight spokes and probably would be interpreted as being a Crismon, while the remaining four allude to, as we shall see, the wheels of the vision of Ezekiel.

\subsection{A Synoptic Theophany}

Identification of the iconographic theme represented in the apse of Sant Miquel has been the subject of debate among scholars who have dwelt on the paintings. Puig i Cadafalch (1936) interpreted the scene as a theophany derived from the second vision of Ezekiel and identified the 12 characters from the lower register as being "people of varying social conditions of Jerusalem".

On the other hand, Charles Kuhn defined the iconography as a combination of an apocalyptic vision and that of Ezekiel, converting the Apostles into the Elders of the Apocalypse, reduced from 25 to 12 (Kuhn 1928, 1930, pp. 9-11). However, the epigraphic study undertaken by the team of the ICAC and the Universitat Rovira i Virgili in 2015 has allowed us to read the didactic character inscriptions that appear together with the figures in the lower register (López Vilar and Gorostidi 2015a), a fact that allows us unequivocally identify the figures as the Apostles (Figure 11).

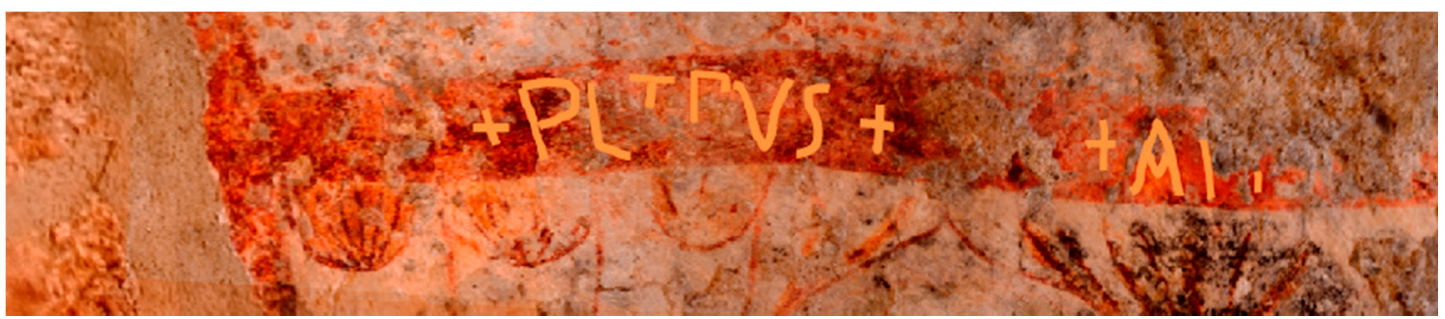

Figure 11. Sant Miquel de Terrassa, wall paintings. Epigraphic inscription: PETRVS. C Jordi López and Diana Gorostidi (with kind permission). 
The third interpretation was that of Grabar (1945), who identified the scene as being the Ascension of Christ as a cultural act in the contemplation of God. ${ }^{5}$

In my opinion, in the apse of Sant Miquel de Terrassa, we find a synoptic theophany that fuses two textual sources in one theme: the Ascension of Christ and the Vision of Ezekiel. Although the primary and hierarchic source of the paintings is the Ascension of Christ (Mark XVI, 19; Luke XXIV, 50-51; Acts I, 9-12), ${ }^{6}$ we find elements of the vision of Ezekiel, specifically the four wheels of the cart and the throne (Ezekiel I, 4-28; X, 1-22). The image resulting from this fusion has lost its meaning as a specific biblical episode, to become a synoptic theophany emphasizing the presence and the divinity of Christ. The historic episodes of the Ascension and the vision of Ezekiel are only a pretext, simple starting points that allow us to explain the theological truths on the Nature of Christ.

What is the origin of this iconographic model? Varying evidence leads me to think that the patrons of Terrassa knew of an Eastern model that may have inspired the paintings of Sant Miquel, specifically found in the theophanies predominant in the Syrian/Palestinian and Coptic art of the 6th-7th centuries. On one hand, some of the iconic elements, such as the four angels holding the mandorla, where Christ ascends to heaven as a "basileus celeste", remind us of the Syrian-Palestinian Ascensions, whose best example is the Rabbula Gospels from the 6th century (Florence, Laur., Plut. 1. 56, c.13v) (Figure 12). In this same way, the imago clipeata of Christ being taken to heaven by four angels also appears in some of the ampullae, a pilgrimage flasks from the Holy Land, dating from the 6th-7th centuries, as in the case of those housed in the Museum of Duomo di Monza (Figure 13), ${ }^{7}$ which preserves the representation of the Ascension of Christ.

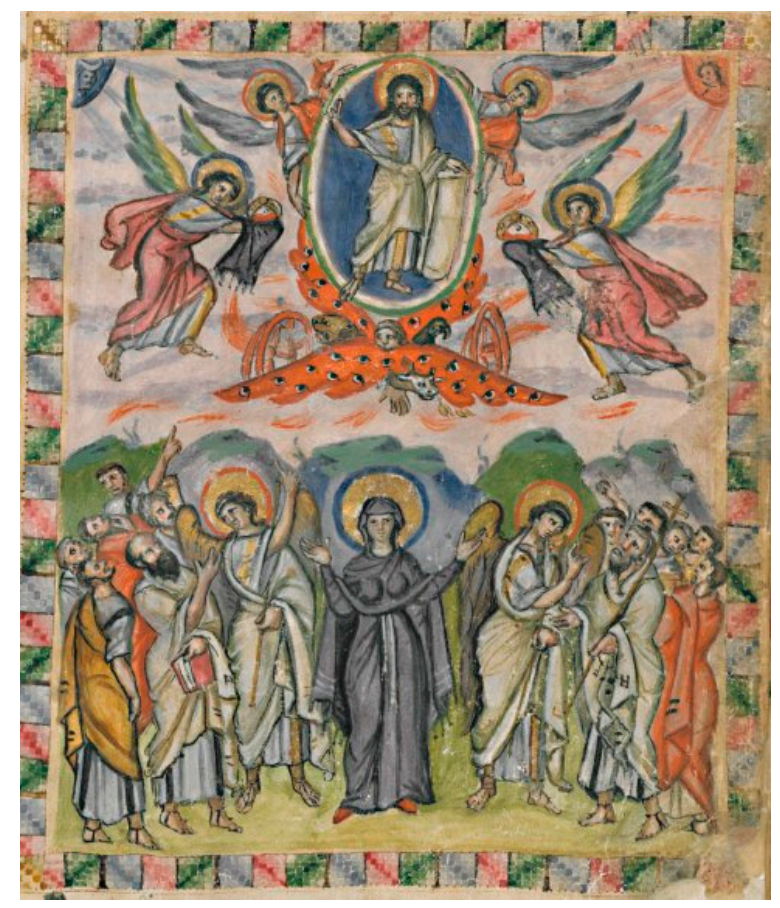

Figure 12. Rabbula Gospels from the 6th century (Florence, Laur., Plut. 1. 56, c.13v). (C) Biblioteca Medicea Laurenziana (with kind permission).

5 Christe (1969, p. 69), Mancho (2012, pp. 343-94), and Ferran (2015) accepted the identification of the theme as that of the Ascension.

6 Regarding the iconography of the Ascension, see (Dewald 1915; Van der Meer 1938, pp. 185-88, 196-98; Belting-Ihm 1960, pp. 95-112, 1989, pp. 43-59; Schiller 1971, pp. 141-64; Schmidt 1991, pp. 572-77).

7 Regarding the ampullae from the Holy Land housed in Monza and Bobbio, see (Grabar 1958). 


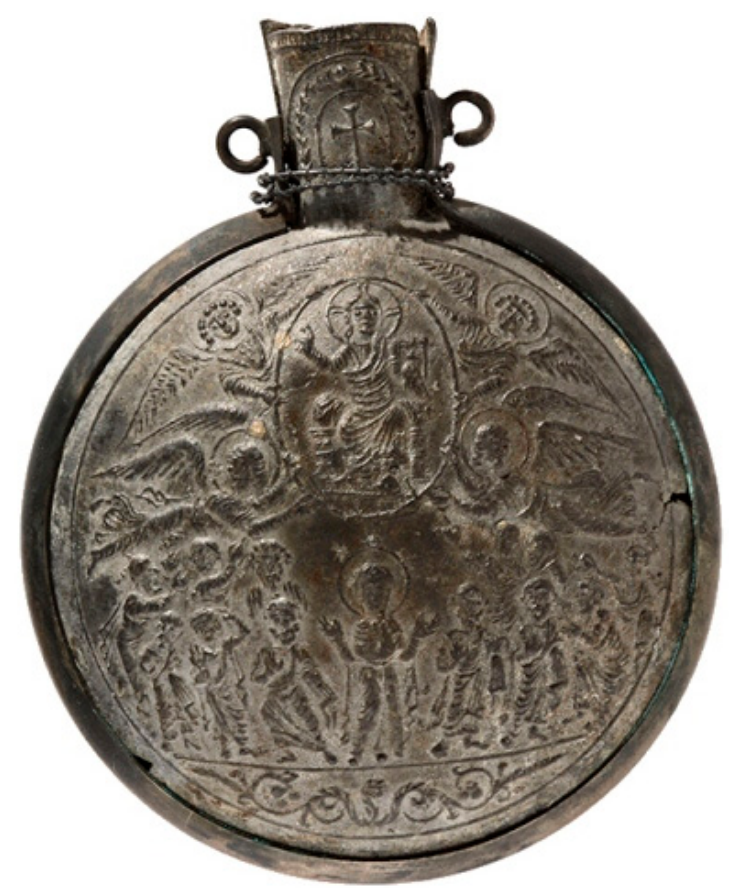

Figure 13. Ampulla $\mathrm{n}^{\circ} 1$ of Monza, reverse. 6th century. (C) Treasury of Monza Cathedral (with kind permission).

However, we would have to search in the Coptic theophanies of the 6th century for the closest model to the scene at Terrassa, such as those at Qubbet al-Hawa, the lintel of El-Moallaka, or those found at the monastery of San Apolo of Bawit: Chapel 17 (Figure 14) and apses of halls 6 and 20 of the Coptic Museum of Cairo (Figures 15 and 16). ${ }^{8}$ We can find one of the most similar examples on the apse of Hall 6 of the Coptic Museum of Cairo, where we see a repetition of iconographic elements like the enthroned Christ, the clipeata images of the Sun and Moon, and the Apostolic College with inscriptions identifying each one of the characters.

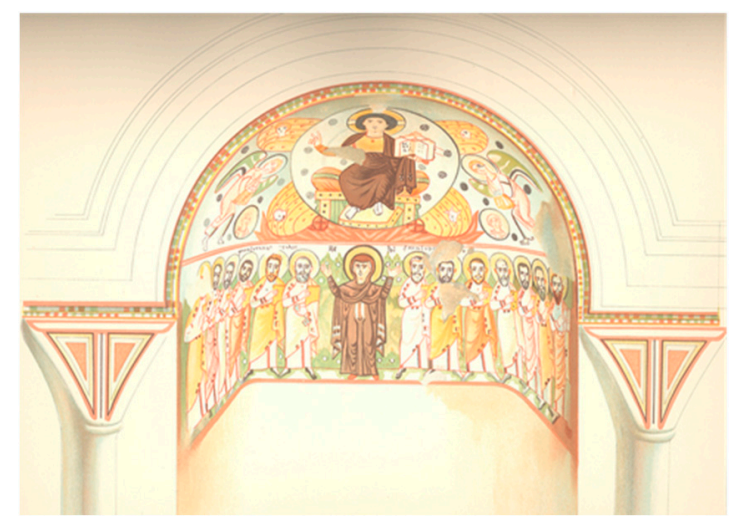

Figure 14. Bawit (Egypt), chapel 17. Aquarelle copy. After Clédat (1904) vol. 1, part two. pl. XLI.

8 For the latest published studies on the pictorial decoration of Bawit, see (Iacobini 2000). The author considers that in the images of Bawit, there is a hierarchic relationship between the different textual sources, with the vision of Ezequiel as their primary source of inspiration (Iacobini 2000, pp. 107-19). On the contrary, Van der Meer (1938, pp. 266-71) proposed a liturgical matrix for the theophanies of Chapels XVII and XXVI of Bawit. The presence of the Trisagion in the book of Christ leads him to think that the theophanies of Bawit are the evocation that figures in the introduction of the Trisagion sung in the liturgy. 


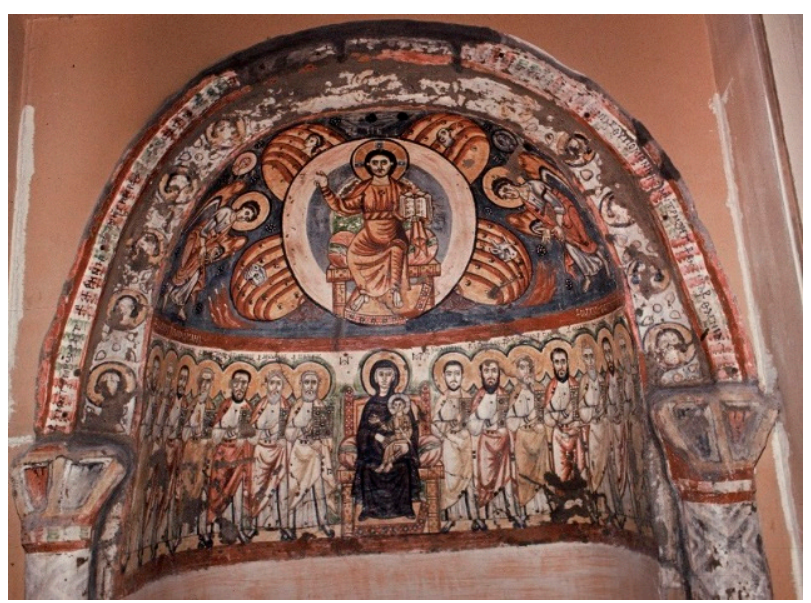

Figure 15. Cairo, Coptic Museum: wall paintings of chapel 6 of Bawit (Egypt). 6th century. C Coptic Museum (with kind permission).

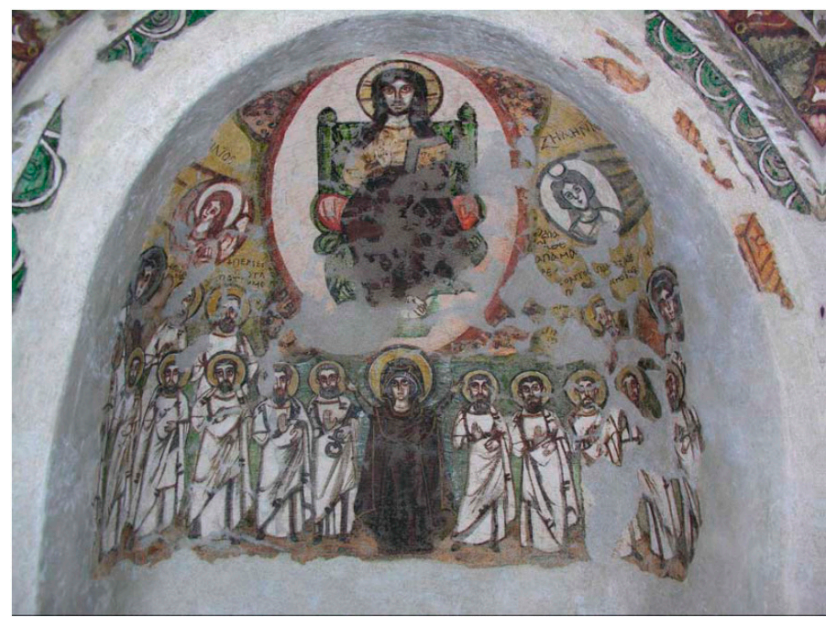

Figure 16. Bawit (Egypt), apse of salle 20, at the present in the Coptic Museum, Inv. No 8012. (with kind permission).

Nevertheless, other iconographic details incorporated into the chapels of Bawit such as the Tongues of Fire, the Tetramorph, the Virgin, and in some cases even the Prophet Ezekiel (Chapel XLV), do not appear at Terrassa. Therefore, in comparison to the Coptic theophanies, the scene at Sant Miquel is more synthetic and hermetic.

In any case, I believe that both the Coptic theophanies and those found at Sant Miquel could be considered to be examples of a single type of stereotypical images, although with some variations, that emerged during the end of the 4th century, within the framework of the Trinitarian conflicts, such as Arianism, which shook the Eastern and Western Mediterranean. In the case of Terrassa, the historical episode of the Ascension is a pretext to explain, via a "theophany", theological truths about the reality of the incarnation and divinity of Christ-themes which were widely debated in the great ecumenical councils of Nicea (325), Ephesus (421), and Chalcedon (453).

Furthermore, the emphasis on a theophany makes the paintings of Terrassa tie in with a broad tradition of apse imagery that includes not only the Coptic Frescoes from Bawit and Saqqara but also the mosaics at Hosios David (Figure 17) and Monastery of St. Catherine at Sinaí. The 5th-century mosaic in the apse of Hosios David at Latomos monastery in Thessaloniki shows the vision of the prophet Ezekiel. The center of the composition depicts Christ enthroned on a rainbow, set within the aureole of blue light. The symbols of the four evangelist holding books are emerging from the aureole. 
In his right hand Christ holds a scroll with written words. The prophets in the composition are Ezekiel and Habakkuk, and that the composition represents The Old Testament Theophany. ${ }^{9}$

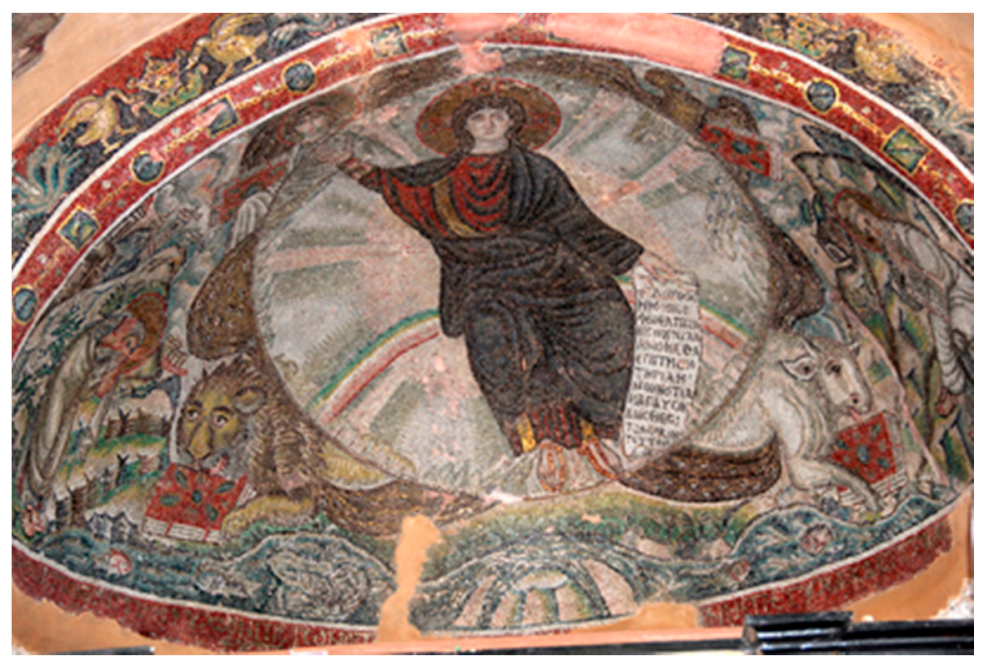

Figure 17. Thessaloniki, mosaic at Hosios David. (c) Manuel Castiñeiras (with kind permission).

The exhibited examples show that at Sant Miquel we do not find a Western Ascension of a Hellenistic variety, which shows Christ ascending into Heaven from a mountain, as we see in the Munich Diptych from the 5th century. In my opinion the wall paintings of Sant Miquel does not present similarities with the preeminent Carolingian Ascensions, as represented in a miniature of the Drogo Sacramentary (9th century), in which Christ ascends to the top of a mountain top and reaches the dextera domini, which emerges from a cloud, ${ }^{10}$ nor with the Ascension of San Joan de Müstair (mid-9th century), a pictorial ensemble that has been associated with the paintings of Terrassa (Mancho 2012).

To this respect, Christe (1969, p. 79) suggested that Eastern Ascensions-Coptic, Syrian or Palestinian-were not accepted in the West before the 9th century. Contrary to this idea, I believe that these dogmatic images could have arrived at the Western Mediterranean in the 6th century and would have been used in those contexts in which the debate over the nature of Christ was relevant. As we shall see later, in the 6th century in the Iberian Peninsula was the setting for the dispute between Arians and Catholics over the double nature of the Verb, and in particular his divine nature, which had been put in doubt by the Arians. The theophany of Terrassa possesses a dogmatic character that is in line with the theological thinking of this time, which also coincided with the time of the existence of the Episcopal See of Egara (5th-8th centuries).

Finally, I think that to have a complete understanding of the meaning of the paintings of Sant Miquel, it is essential to place them in relation to the building's functionality. In this sense, archaeological excavations have shown Sant Miquel to be a funerary building (Garcia Llinares et al. 2009, pp. 127-45; Garcia Llinares et al. 2015). I believe that the vision of Christ must be specifically associated with the funerary space. In this way, and in the eyes of the faithful, the paintings were also possibly conceived to be a synthetic image with a clear message of salvation: the ascending Christ is at once an evocation of the Resurrection of Christ and of the Second Parousia. Christ as the savior and judge at the end of time, ideally fulfilled its function to intercede on behalf of the souls of the deceased donors. In the Acts of the Apostles, it is written that at the moment of the Ascension, "two men dressed in white

9 Regarding the mosaic of Hosios David see (Snyder 1967, pp. 145-52; Pentcheva 2000, pp. 139-53; Semoglou 2012, pp. 231-39; Vinulović 2018, pp. 175-86).

10 Dewald recognized three predominant iconographic types within Carolingian art: (1). Christ ascending to the top of a mountain top in the presence of angels, the Apostolic College and the Virgin; (2). Christ, shown with his back to the spectator, walking toward the top of a mountain of rocks and raising his left hand to Heaven; and (3) Christ emerging between the disciples and raising his left hand toward the dextera domini. See (Dewald 1915, pp. 296-97). 
appeared to the Apostles and said: that same Jesus who ascended into Heaven before you, shall come again in the same manner in which you saw Him depart to Heaven (Acts, I, II)". From the Eastern liturgies of Saint Mark and Saint Basil, there arose a clear correspondence between both themes. In the sacrament of the Eucharist, the priest invokes the Second Coming of Christ through the Ascension: "For as often as you eat this bread and drink from this cup, you proclaim the Lord's death until He comes," and then pronounced, "you confess my resurrection and my Ascension". ${ }^{11}$. In an essential way, the Ascension was always understood, too, as the promise of the Second Coming as the angels tell the apostles that he will come again in like manner, which was understood to mean that that place was where Christ's return and judgment are always imminent. The paintings of Sant Miquel gave a tangible form to ideas of death and salvation.

\subsection{Theophany as Presence}

The paintings of Sant Miquel have an element that, in my opinion, has not garnered the attention it deserves. In the apse's lower register, framing the depiction of the Apostolic College, we find two draperies enriched with segmenta and gathered together by a central knot (Figure 18). It is an ornamental resource that was frequently used in Late Antiquity which we can find in examples such as San Vitale or San Apolinar Nuovo of Ravenna (Figure 19), or in the Tomb of the Apostles (s.V) preserved in the Archaeological Museum of Tarragona (Figure 20).

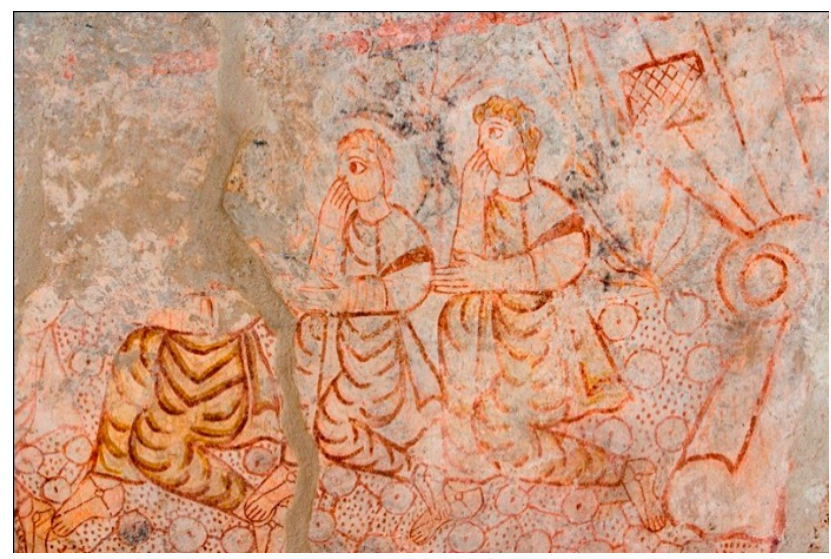

Figure 18. Sant Miquel de Terrassa, wall paintings. Detail of the draperies. (C) Teresa Llordés (with kind permission).

I believe that in Terrassa, these draperies did not solely serve a decorative purpose, as some authors have suggested (Mancho 2012), but rather served as the evocation of an act of contemplative worship, which used the interior of the church as its setting. It is worth thinking that the paintings of Sant Miquel were probably hidden behind a veil which would be uncovered before the faithful at certain moments. This religious artifice, inherited from the Mystery religions, was used by Christian iconography to show invisibility and to emphasize divine presence (Grabar 1945). As mentioned previously, the goal of the representation of the theophany of Sant Miquel consists not only in commemorating a specific historic episode like the Ascension but to also bring the faithful before the very manifestation of divinity: the worshipper becomes an eyewitness to the theophany. Consequently, the unveiled image must be contemplated as a ritual revelation, having its value as a mystical apparition.

11 See (Notre messe 1963, pp. 61, 68-69). 


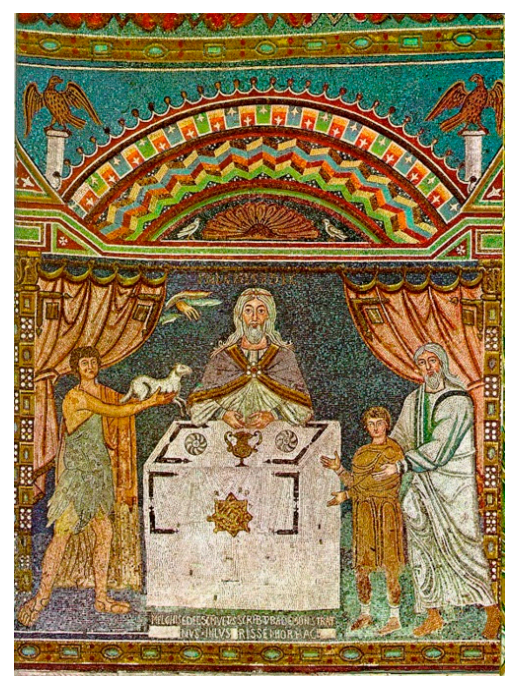

Figure 19. Mosaic of Sant'Apollinare in Classe, Ravenna (Italy). Sixth century. Abraham, Abel, and Melchisedec (C) Author: Sailko.

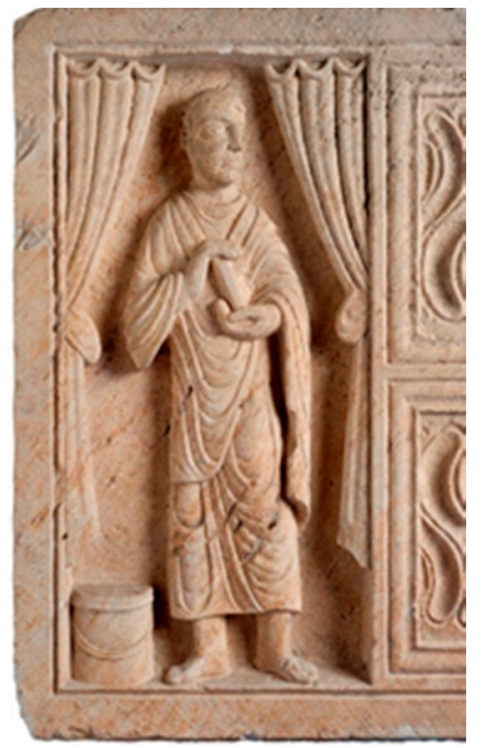

Figure 20. Sarcophagus of the Apostles. 5th century. Museu Nacional Arqueologic de Tarragona (C)MNAT (with kind permission).

With this idea in mind, archaeology has demonstrated the existence of frames enclosing the opening of the apse in various churches of Visigothic Spain (Rodríguez G. de Ceballos 1965; Schlunk 1971; Bango Torviso 1997). A curtain was placed over these frames, which restricted access to the altar, adorning the arch of the entryway and hid the apse from view. In the floors of many ancient churches from the Visigothic Period, one can still find, under this access archway which we shall call a "crossing", signs marking the places occupied by these frames. ${ }^{12}$

These draperies should be explained thus as being a reference to the "revelation" of a mystery: Christ manifests his supernatural character through the historical episode of the Ascension. This hypothesis is exemplified by a paradigmatic piece of Coptic art, specifically the wooden threshold or lintel of El-Moallaka (Figure 21) where the curtains were also used to unveil an Ascension theophany

12 See the example of San Pedro de la Mata (Casalgordo, Sonseca, Toledo) or of Santa María de Melque (San Martín de Montalbán, Toledo). 
(Sacopoulo 1957; Grabar 1970). The wooden lintel from El-Moallaka was re-dated some time ago by Leslie MacCoull ${ }^{13}$ to the 8 th century (734-735) on the basis of a correct reading of the inscription. As Glenn Peers has pointed out the Ascension is implicated in a dynamic unfolding of revelation, through layers of history and ritual, into the present (Peers 2007, pp. 25-46).

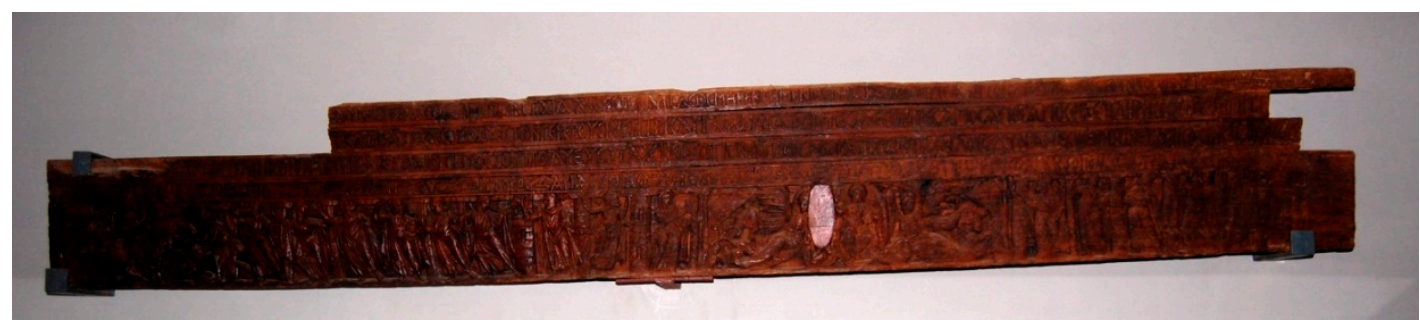

Figure 21. Lintel from El-Moallaka (8th century). (C) Cairo, Coptic Museum (with kind permission).

\subsection{Singing to Christ Emmanuel}

The second, and truly fascinating element of the paintings of Sant Miquel is the gesturing of the Apostles, represented in a position of genuflection, with one hand on an elbow and the other on a mouth (Figure 22). According to Grabar (1945, p. 126), this genuflection at Terrassa has an Egyptian prayer ritual as its origin ${ }^{14}$. As far as the hand-to-mouth gesture is concerned, it was a gesture accompanying the prayer or reading of the psalms, and at once a sign of protection against demons that could enter through the mouth. We find ourselves, then, before a sum of liturgical gestures whose origins are in Coptic Egypt, perfectly regulated within a strong tradition: avoiding the entrance of evil through the mouth while singing the psalms.

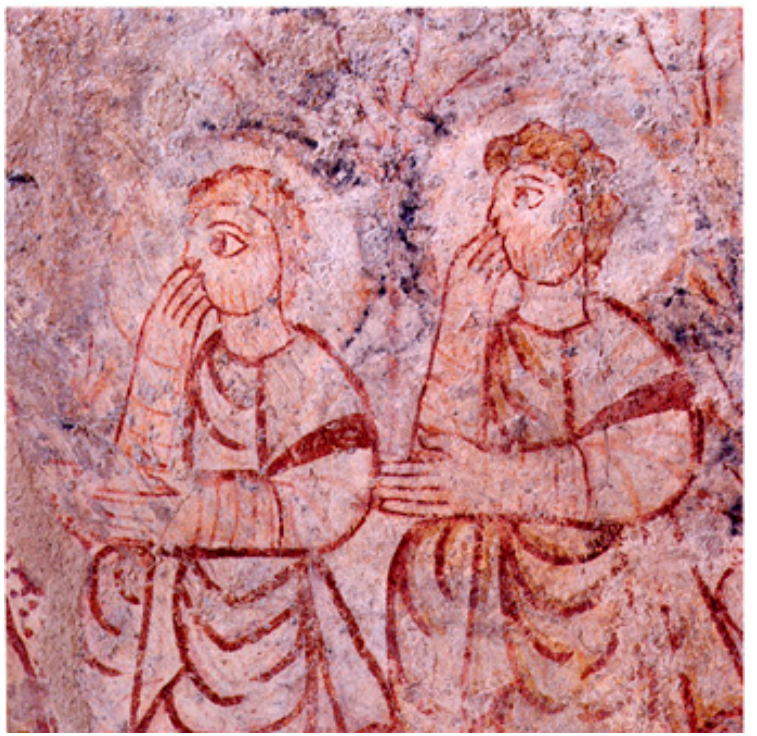

Figure 22. Sant Miquel de Terrassa, wall paintings. Detail of the Apostles. (C) Teresa Llordés (with kind permission).

13 "There dwells all the fullness of the Godhead, on the peak of truly heavenly Sinai/[ . . ] the angels and they ceaselessly honor him with thrice-holy voice singing and saying: Holy, holy, holy are you, $\mathrm{O}$ lord: heaven and earth are full of your holy glory/For the are filled with your greatness, O Lord of great mercy, as you are invisible in the heavens amidst manifold powers, and you were content to dwell together with us mortals/ having become incarnate from the Mother of God, Mary, who has never known man. Be a helper to Abba Theodore the patriarch and George the deacon and oeconomus. Pachon 12, indiction 3, year of Diocletian 451". Transcription by Mac Coull (1986).

14 Carles Mancho considers the Apostles to not be kneeling, but rather seated (Mancho 2012, p. 375), and compares the paintings of Sant Miquel with a Reichenau Gospel from the first quarter of the 9th century (Munich, Bayerische Staatsbibliothek, Cod.lat. 23631, fol. 197r), which represents the Apparition of Christ to the Disciples (John 20, 19-23). 
In this sense, and following the hypothesis set forth by Grabar, I believe that the image of Terrassa could well be a type of visual codification of a possible form of chant or specific repertoire, originating in the Eastern liturgies. In favor of this hypothesis, we have the inscription from Chapel 28 of Bawit, in which two monks identified as singers of psalms ( Terrassa: one hand over their mouths (a way of muting?) and the other on their elbows (which makes the sound resonate in the skull) (Figure 23). I am inclined to think that it has a syncretism which has its origins in Pharaonic Egypt, specifically in Ihy, God of Music, who was habitually shown as kneeling and with a finger on his lip (Maniche 1991) (Figure 24).

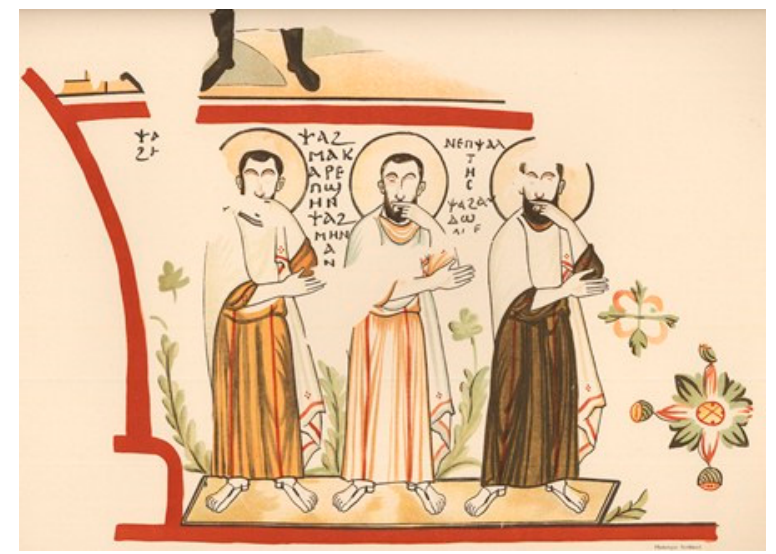

Figure 23. Bawit Monastery. Chapel 28. Egypt. Aquarelle copy. After (Clédat 1904).

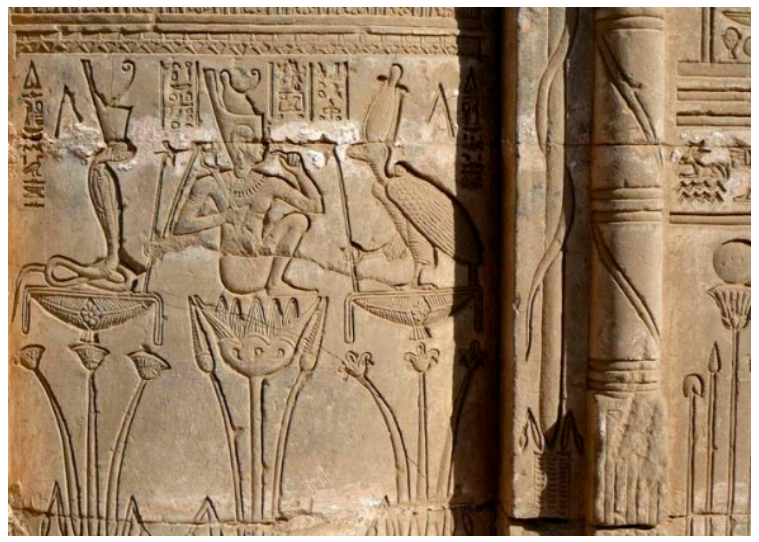

Figure 24. Relief depicting God Ihy at Dendera (Egypt). (C) Marie-Hélène Cingal.

In Ancient Egypt, singers generally appear as being represented by a hand covering their ear, and Coptic liturgy, by extension, did the same (Kuhn 2014, pp. 67-77). They also appear to be making different signs with their hands, which make reference to a "quironomia" or pantomime, which represent signs and certain characteristics of songs in the first centuries of the Christian Era. In the mural paintings and reliefs of Ancient Egypt we can see the same gestures in singers like the famous Iti, or the singer who appears on the tomb of Nenchefka, both the Egyptian Museum of Cairo (Figure 25). 


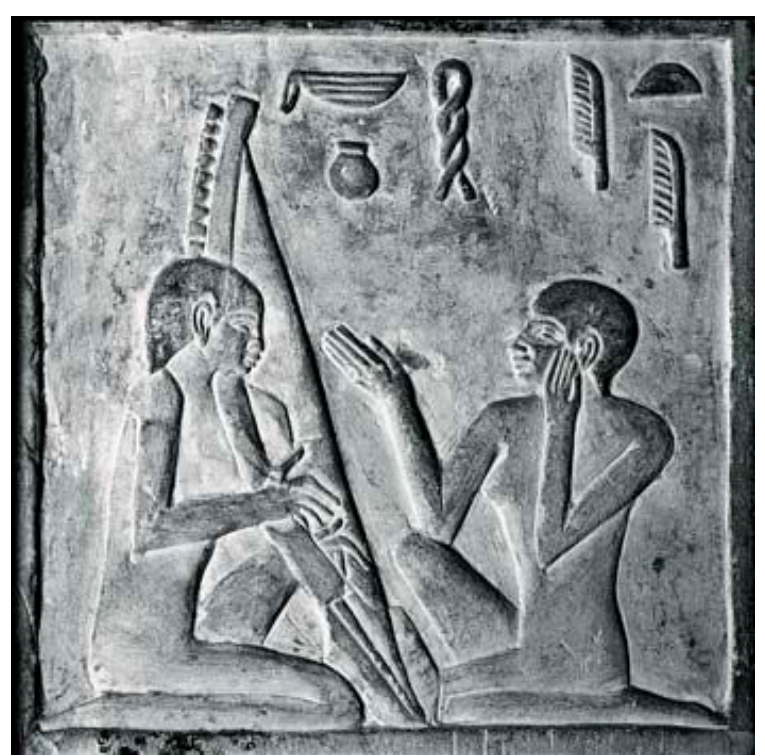

Figure 25. Ancien Egyptian singer, Iti in Tomb of Nikaw-ra. (C) Egyptian Museum Cairo.

Therefore, I believe that the gestures of the Apostles of Terrassa do not only allude to the mystical silence of contemplation, as suggested by Henry Maguire ${ }^{15}$ or André Grabar, but rather that the Apostles were singing before the revelation of the theophany in the apse. In this sense, I believe that the image of the Apostles could be an artistic evocation of some of the chants practiced in the Mozarabic liturgy, be it in the recital of the psalms, hymns or the Trisagion ${ }^{16}$, probably emphasizing the divine character of "Christ Emmanuel".

\section{A Program against Arian Heresy?}

Without a doubt, one of the most singular elements of the paintings of Sant Miquel de Terrassa is the presence of the inscription "Emmanuel" appearing in the halo of Christ. Although the term appeared for the first time in the prophecy of Isaiah about the Messiah (Isaiah, VII, 14), it is Matthew who reveals the meaning of the name (Matthew, I, 23):

The virgin will conceive and give birth to a son, and they will call him Emmanuel (which means "God with us).

This is, therefore, a titulus applied to Christ, as the son of a virgin woman and God. In my opinion, both the presence of the titulus "Emmanuel" and the choice of the image of the Theophany-Ascension we find in Terrassa, should be interpreted as an affirmation by the Catholic Church before the Arian heresy that denied the dual nature of Christ. In the Eastern theophanies (Coptic, Syrian or Palestinian)

15 According to Maguire, in Middle Byzantine art the hand clasped to the mouth in depictions of the Ascensions means simple silence or speechlessness. He refers to the mid-9th century fresco of the Ascension in S. Clement in Rome, where one of the apostles standing on the right of the scene claps one hand over his mouth, while in his other he hold a scroll. An explanation of his actions may found in a poem by the 7th-century Pope Honorius I, which describes "The Apostles in Amazement at the Ascension of Christ to the Heavens". The apostles also cover their mouths with their hands in the tenth-century Ascension painting at Ayvali Kilise in Cappadocia. See (Maguire 1977, pp. 123-74). About the gesture in Byzantium see also (Brubaker 2009, pp. 36-56).

16 The Trisagion is an echo of the biblical passage in which the seraphim sing out to the Lord: "Holy, Holy, Holy is the Lord God Almighty" (Isaiah 6,3). It is repeated in the Apocalypse: "Holy, Holy, Holy is the Lord God Almighty who was, and is, and is to come" (Apocalypse 4,8). It emerged in Eastern Christianity and was often used as an instrument to combat the heresies that cast doubt on the dual nature of Christ. From the primitive form of Trisagion, Hispanic priests wrote new texts emphasizing the power and royalty of Christ through the use of Apocalyptic texts. Documented for the first time at the Council of Chalcedon (451), it was introduced to the Hispano-Mozarabic liturgy due to the influence of the Eastern liturgies (Pinell 1998, pp. 152-53; Martín-Delgado Sánchez 2018, pp. 64-65), and was recited by ministers serving at the altar, by clerics of the choir and by worshippers. 
we have seen before, the heavenly triumph of Christ proves the integrity of his divine nature ab aeterno, while the Virgin is proof of his embodiment as a man.

The importance of the name Emmanuel as a proclamation of the dual nature of Christ explains that this term was widely used at this time by the Christian exegesis to combat the heresies (Arian, Monophysitism, Nestorianism), which were fought in the Great Eastern Ecumenical Councils: Nicea (325), Ephesus (431), Chalcedon (453) and Constantinople (381-553). From there we see the presence of the inscription Emmanuel not only in great figurative cycles like Terrassa but also in icons ${ }^{17}$ and in the ampullae in the Holy Land such as those preserved in Monza and Bobbio (Grabar 1958), dated to be from the 6th century (Figure 26). Some of these ampullae, which religious pilgrims would acquire as "souvenirs", have on one side a representation of the Adoration of the Magi with an enthroned Virgin, along with the inscription EMMANOYHA (Emmanuel), while the other side depicts the Ascension of Christ.

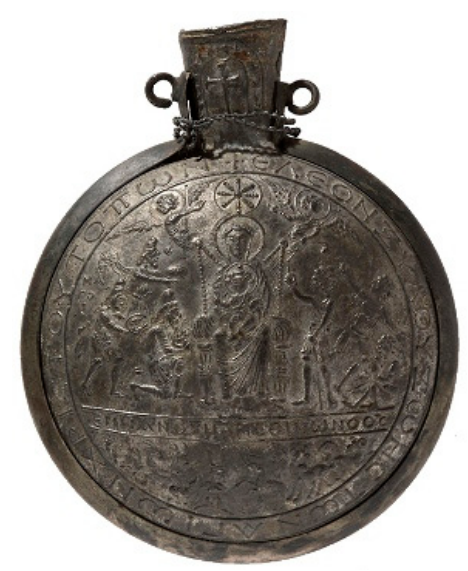

Figure 26. Ampulla $\mathrm{n}^{\circ} 1$ of Monza, obverse. (C) Treasury of Monza Cathedral (with kind permission).

It is important to remember that although the doctrine of Arius was condemned by the Nicea Council (325), in the West it enjoyed a great popularity among the Germanic people, as it did with the Visigoths, who professed the Arian faith and had to contend with the Catholicism of the people they dominated. The Iberian Peninsula did not keep its distance from heretical conflicts originating in the Byzantine East, although they did arrive later. Different indications compel us to reconsider the magnitude of the conflict, above all to propose the hypothesis that a dogmatic will on the part of the Catholic Church hides behind the choice of the iconographic theme of Terrassa.

In the first place, for 37 years the Arians prohibited the celebrating of the Councils of the Catholic Church in Hispania. After the Council of Valencia of 549, Catholic bishops did not reunite again until the reign of Recaredo, who converted to Catholicism in 589. We know that 9 Catholic synods were held between the years 506 and 549 , but none was documented to have existed in the 36 years afterward (549-586) (Thompson 2014, p. 57). The prohibition, recognizing the veto, was lifted at the Council of Toledo of 589 (Vives 1963, pp. 107-45):

And as for many years, the threatening heresy did not permit the celebration of the council of the Catholic Church, God, who was pleased to have extirpated the aforementioned heresy from our midst, admonished us to restore the ecclesiastic institutions according to the ancient traditions.

In the second place, Catholic authorities described the reign of Agila (549-555) as an oppressive regime. Afterward Leovigildo (572-586) was accused of persecuting the Catholics in his kingdom

17 Proof of the term in the East resides in an icon housed in the picture gallery of the Monastery of Santa Caterina del Sinai (7th century), where the image of a majestic Christ appears joined by the inscription E[MMA]NOYHA. See (Weitzmann 1976, p. 41, n.B16). 
(Thompson 2014, p. 109) and even expelled non-Arian clerics from the cities under his power (Vallejo Girvés 2012, p. 243). Among those exiled to Christian episcopal sees, it is worth mentioning Juan de Bíclaro (c. 540-621), who upon returning to the Iberian Peninsula after a prolonged stay in Constantinople, was exiled to Barcelona in the year 577 on orders from Leovigildo (Vallejo Girvés 2003), and where he remained until 587/588. Later, in 591, he was named Bishop of Girona. As Bishop, he subscribed the Second Council of Zaragoza of 592, the Council of Toledo in 597, the Second Council of Barcelona of 599 and the Council celebrated at the Episcopal See of Egara in the year 614.

In the third place, Julia Bertrán de Heredia has recently demonstrated that in the case of Barcelona, we have a data that allows us to propose the hypothesis for a Catholic see and an Arian see in the capital (Bertrán de Heredia 2019, p. 156). ${ }^{18}$ No less significant is the case of Zaragoza, where Bishop Maximo celebrated the Second Council of 592 with the objective of eradicating the after-effects of the Arian period. ${ }^{19}$

In the fourth place, during the Council of Braga of 572, any and all suspicion of heresy was urged to be denounced (Vives 1963, pp. 78-106):

If any bishop or presbyter or deacon of any bishop engages in a heretical opinion and would be excommunicated for this reason, no bishop shall admit him in his Communion if he does not satisfy all those present before a common assembly with a confession of his faith. This same condition is established for the lay faithful in case they would be accused of heretical opinions.

In this sense, I believe that the iconographic program designed by the creators of the pictorial decoration of the apses of Sant Miquel and Santa Maria is neither arbitrary nor can they be read independently. On one hand, in the pictorial decoration of Santa Maria (which the historiography unanimously situates at the same chronological moment as the paintings of Sant Miquel), the human nature of Christ is underscored, via the different scenes of the Passion and his public life (Figures 27 and 28). In this respect, the representation of enthroned Virgin and Child, the Theotokos Virgin, a title conceded at the Council of Ephesus (431) becomes even more remarkable, and with a very clear objective: to proclaim that Jesus was completely God and Human and that his two natures were inseparable.

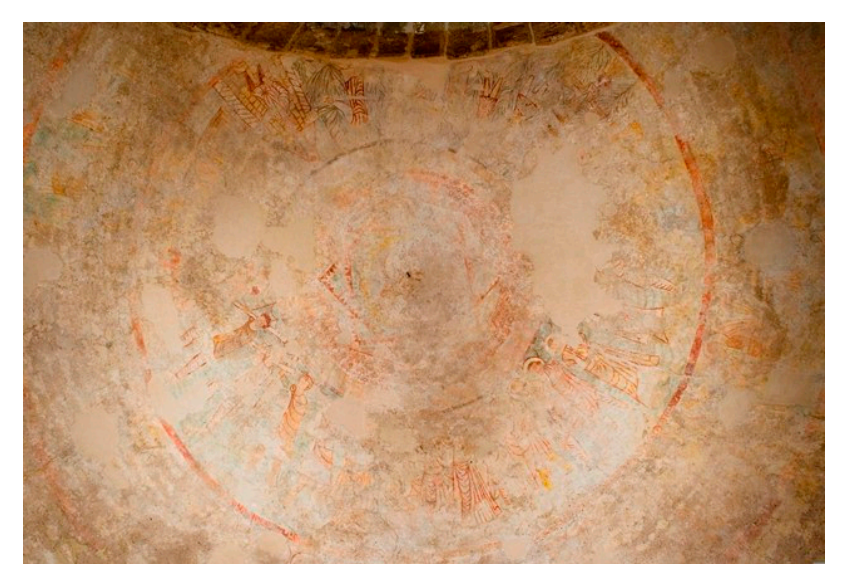

Figure 27. Santa Maria de Terrassa, wall paintings. (c) author.

18 According to the Júlia Bertrán de Heredia, it is very probable that when the Visigoths installed themselves in Barcino, they would have occupied the official episcopal nucleus, which today is under the present cathedral and under the Plaza del Rey, and that the Catholics were ousted to Sant Just i Pastor, where an older Church probably already would have existed, a fact that would justify the relocation of the Catholic Episcopal group to this part of the city.

19 Three canons were approved at the Council, stating that presbyters and deacons should be reordained and that Arian churches that had been reconsecrated by Arian bishops without receiving the blessing of a Catholic Bishop must be reconsecrated. See (Vives 1963, pp. 154-55; Escribano Paño 1998, p. 85). 


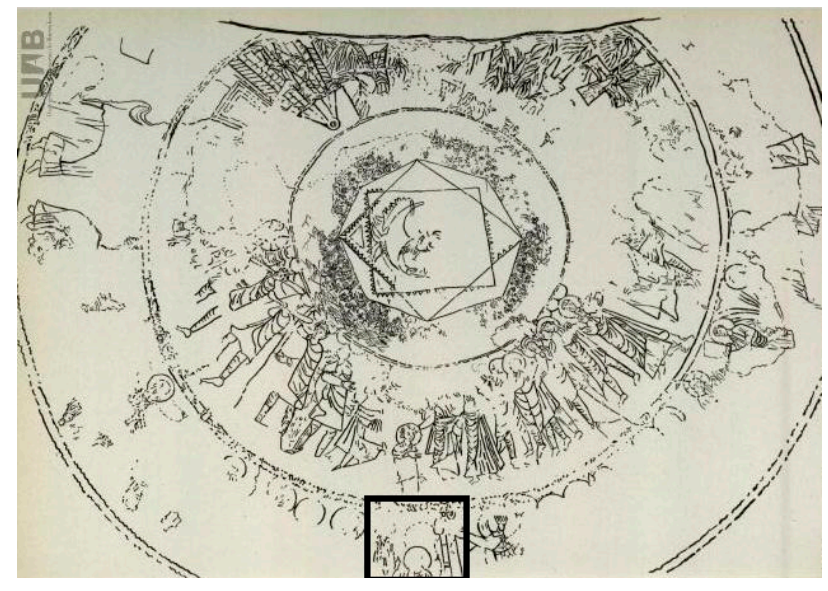

Figure 28. First tracings of the pictorial decoration of Santa Maria de Terrassa. In the lower register we can see the detail of the Virgin and Child surrounded by Apostles and Prophets. Source: Josep Puig i Cadafalch. 1948. Noves descobertes a la catedral d'Ègara. Barcelona: Institut d'Estudis Catalans.6. The Reception Line of the Byzantine East.

To this end, several authors have drawn attention to the absence of the Virgin in the theophanic Ascension of Sant Miquel. In effect, it is a common element of Eastern Ascensions. I believe that this circumstance is due to two motives: in the first place, the figure of the Virgin does not appear in the canonical texts of the Ascension, and as such her presence is not a sine qua non condition; in the second place, Sant Miquel represents a synoptic theophany that does not aspire to underscore the reality of the Incarnation through the Virgin (already represented in the apse of Santa Maria), but rather the return of the Verb to the Father and divine character of Christ in Glory. This would justify her absence at Sant Miquel.

In a context in which the controversy was alive in the Iberian Peninsula in the 6th century, it is logical to think of a recurrence to an ad hoc iconography as a contribution to the controversy by the Catholic Church. To this end, Eastern models were employed, as we have seen in Bawit, El-Moallaka or Qubbet al-Hawa (Egypt). It is, without a doubt, a time of the creation of new iconographies with specific meanings and intentions, of dogmatic images that are converted into mass-media to illustrate the conclusions derived from the great ecumenical councils of Nicea (325), Ephesus (431) and Constantinople (381-553) against the heresies. ${ }^{20}$

Since the first studies conducted by Puig i Cadafalch, different researchers have underscored the exceptionality of the paintings of Sant Miquel and Santa Maria de Terrassa for their similarities with the art of the Eastern Mediterranean (Puig i Cadafalch 1936; Grabar 1945; Christe 1969; Ferran 2015). In effect, and as we have seen, we find within the decoration of the paintings of Sant Miquel the marks of a primitive repertory of Christian art very much related to the context of the Eastern Byzantine, especially with Coptic Egyptian art of the 6th century. The paintings of Sant Miquel show revealing similarities to the monastery paintings of Saint Apollo of Bawit and Qubbet al-Hawa in Egypt, whose chronology situates them as being to the 6th century.

20 I do not share a belief in the proposal set forth by Professor Carles Mancho, who considered the paintings of Sant Miquel to have been commissioned by the Bishop of Barcelona, Frodoí (861-890), as a response to the clerics adhering to the ancient Hispanic liturgy, who had attempted to usurp episcopal rights of those accused of heresy. For that, he would have used the theme of the Ascension, which would equate the Hispanic rite with the Adoptionist heresy, a doctrine that argued that Christ would have been elevated to a category of the divine by appointment by God himself through his adoption. I believe that this hypothesis does not take two important premises into account. On one hand, Elipando, Archbishop of Toledo and one of the main defenders of the Adoptionist heresy, died in the year 805 at the See of Toledo with no disciple to continue his thesis. On the other, in the year 794 at the council of Frankfurt and presided by Charlemagne himself, Adoptionism was condemned. Consequently, the conflict involving Adoptionism would be very far from the time of Frodoí. 
Today we do not know which the means for this artistic transmission were, as well as the reasons which led the "doers" of Terrassa to select such a peculiar and unique repertoire of topics, motifs, and inscriptions.

In this sense, I believe that the assimilation of Eastern repertoires into the paintings of Terrassa cannot be attributed to only one form of reception, but rather that it can be attributed to different ones. In the first place, I believe that we must evaluate to which point the assimilation of Eastern liturgies, within the Mozarabic or Hispano-Visigothic liturgy, could have influenced the selection of certain iconographic themes. D.S. Bäumer was one of the first authors to find a strong influence of Byzantine Eastern liturgies within the Mozarabic liturgies, who attributed the contact of the Goths with the Greeks (Bäumer 1905, p. 243). Although if taken as a whole, the Hispanic Visigothic liturgy is a Western liturgy, imported from Rome (Ferotin 1904, p. 12), various authors have signaled points of contact with Eastern liturgies. ${ }^{21}$

Father Enrique Flórez attributed such influences to the arrival of people from the Orient, both by land and by sea (Flórez 1754, p. 220). In this respect, it reminds us of the letter that Pope Hormisdas (514-523) wrote to the Joan, Archbishop of Tarragona, in the year 517, in which he spoke of Greek clerics convening in the province of Tarragona ${ }^{22}$. According to Flórez, it is from these clerics from which many ceremonies were taken, which had a large influence on the changes in Mozarabic rites. ${ }^{23}$

In the second place, this news from Father Flórez leads us to propose a second possibility for this context of transference: firsthand knowledge of these themes and iconographies through journeys to holy places in the Byzantine East. Concerning this idea, I believe that the metropolitan See of Tarragona, to which the Episcopal See of Egara was subordinate, could have played a determining role both in receiving clerics coming from the Eastern Mediterranean, as well as in the journeys to the Orient by clerics from the episcopal sees of Tarragona, such as Terrassa. To the example of the clero Graecorum documented in Tarragona in the year 517, we should add other testimonials confirming the contacts, through travel, with Coptic Egypt. It is precisely coming from Tarragona where we find a tombstone (dated from between the 5th-6th centuries) with a funerary inscription attributed to an ecclesiast named Thecla (of Egyptian origin), who was buried in a martyrial basilica dedicated to San Fructuoso, in Tarraco. It read as follows:

Haec hic beata Thecla

virgo X $\rho \iota(\sigma \tau \sigma v)$, ei patria Aegypt(us).

Vixit ann(is) LXXVII, ut meruit

in pace requievit $D$ (omi)ni (hedera).

Its epigraph could be translated as: "Here lies the blessed Thecla, virgin of Christ, whose homeland was Egypt. She lived 77 years; as she deserved, she rests in the peace of the Lord". 24

It is not the only documented case: an inscription-lost today-of an altar table in Tarragona which was transmitted by E. Flórez recalls the Alexandrian origin of a cleric named Esteban:

21 For further information of the reception of Western Liturgies see: (Díaz y Díaz 1967; Blázquez Martínez 1967; Gros i Pujol 1992).

22 Hormisdas, Ep. 24, ad Ioannem Tarraconensem, PL 63,422 i 84, 819-820: “Salutantes igitur caritatem qua jungimur, per Cassianum diaconum tuum signifi camus, nos direxisse generalia constituta, quibus vel ea quae juxta canones servari debeant competenter ediximus, vel circa eos qui ex clero Graecorum veniunt, quam habere oporteat cautionem, suffi cienter instruximus". In the same letter, Hormisdas expressed that Ioannes deserved the affection of Christians due to his loyalty to the norms of the Catholics and the Fathers. Consequently, he conferred the mission to restore Hispanic churches to the ancient discipline: "remuneramus sollicitudinem tuam, et conservados privilegiado metropolitanorum vices vobis Apostolicae sedis eatenus delegamus." We can deduce that in Hispania there existed situations of heresy, opposed to the Catholic faith. See (Amengual i Batlle 2013; Gomá 1907, pp. 689-93; Del Amo Guinovart 2001, p. 275).

23 Among the rites most profoundly marked by an Eastern-Byzantine influence, the Greek Trisagion specifically figures (Presedo Velo 2003, p. 116), a rite which Van der Meer saw as the source of the theophanic images from Coptic Egypt, with which Terrassa has an undeniable bond.

24 According to the latest studies (López Vilar and Gorostidi 2015b), no relationship exists between this Thecla and the cult of worship in place during the medieval period of Santa Tecla as patron saint of Tarragona, contrary to what some authors have proposed (Del Amo Guinovart 1997). 
Stephanus Alexandrinus in honore Dei et omnius sanctorum die VIII idus Apriles anno tertio ordinationis eius cum suis sub pontificatu Georgii episcopii sanctissimi. Sigillum hic esto. (Flórez 1770, pp. 93-94; Del Amo Guinovart 2001, p. 275)

The two cases mentioned here are examples of a movement, which most certainly would have been more widespread. We cannot forget that during the government of Emperor Justinian I (527-565), a favorable context arose in the Mediterranean for circulation and transference. Within the framework of Justinian's Renovatio imperi, the Byzantine Empire expanded to the West, with the recovery of Northern Africa from the Vandals (533-534), Sicily, Sardinia, and Dalmatia (534), Ravenna (540) and Italy (555). From the year 552 and until the year 625, the Byzantine Empire maintained a strong presence in the south and the eastern part of the Iberian Peninsula, a region that became integrated into the Empire under the name Spania. However, the creation of the Byzantine province of Spania does not appear to have been the way of artistic reception from Byzantium in the Western Mediterranean. ${ }^{25}$

In my opinion, the existence of foreign communities-Greeks, Syrians, Egyptians-who were well-established in northeastern Spanish society, leads me to believe that one of the reasons for this close Hispano-Byzantine relationship could be the travels of priests. ${ }^{26}$ However, I believe it would be an error to show relations with Byzantium as being one-way. We cannot forget that the Eastern Mediterranean was also an attractive destination for pilgrims who, beginning on the 4th century, visited places of worship such as the temple dedicated to Saint Thecla of Seleucia (Syria). ${ }^{27}$ Among others, we must distinguish the work of the Hispanic woman Egeria, who visited it between the years 381 and 384 and wrote a description in Sumerian of her celebrated Itinerarium (Wilkinson 1971, pp. 28-29; Maraval 1982; Arias Abellan 2000, pp. 11-12).

From an early date, the worship of Saint Thecla enjoyed widespread devotion in several areas of the Eastern Mediterranean, especially in Egypt, and whose sanctuary was located near the well-known Monastery of Saint Menas, in Abu Mina, in the area of Lake Mariout (Davis 2001, pp. 127-28).

The miracles performed by Menas and Thecla converted their sanctuaries into important centers of worship for the Coptic Church in the 6th century. ${ }^{28}$ The large amount of ampullae coming from the northern region of Egypt, with the joint representation of Thecla and Menas, has led to thoughts of an interaction between both cults of worship in the same area of the Mariout region, in the environs of Alexandria (Davis 2001, pp. 133-36; Bangert 2006; Anderson 2007). ${ }^{29}$ These small terracotta flasks contained holy water and were sold in the vicinity of the temples as "curative" souvenirs. Today, hundreds of these ampullae survive in museum collections throughout the Mediterranean world (Figure 29).

Commerce and travel to these centers of worship in Coptic Egypt possibly favored the knowledge of certain themes and iconographies, which surfaced after the heretical conflicts that ravaged the East. Regarding contact with Coptic Egypt, I believe that in the 5th century, the existence of a basilica dedicated to Saint Menas in Sentmenat, a place very close to Egara, was extremely significant). In 1992, the archaeological remains of a building of Christian worship, dated from the 5th century, were found on the church grounds of the old church dedicated to "San Mena", in Sentmenat (Barcelona) (Roig Buxó et al. 1995)..$^{30}$ With the presence of a Christian church from the 5th century related to the

25 For the discussion of this topic see especially (Schlunk 1945, 1964; Vizcaíno Sánchez 2009, 2013).

26 See (Keay 1996, pp. 18-43; Vallejo Girvés 2004, pp. 117-54).

27 For a general description and study of the cult of Santa Tecla, see (Davis 2001; Fitzerald Johnson 2006, pp. 67-112; Semoglou 2014).

28 By the sixth century, Abu Mina had been transformed into a huge pilgrimage center whose focal point was the tomb of the martyr. See (Drescher 1946; Grossmann 1989, 1998, pp. 291-302; Papaconstantinou 2007, pp. 350-67).

29 Davis (2001) includes a catalog of devotional ampullae and the images of Saint Thecla in frescoes and funerary stelae. There are other known manifestations of the worship of Saint Menas in Catalonia: there are two ampullae housed in the Museu Episcopal de Vic and the Museu Arqueològic in Girona.

30 We only know of two churches in Catalonia dedicated to Saint Menas: Sant Mena de Sentmenat (Vallès Occidental) and Sant Mena de Vilablareix (Girona). 
worship of San Mena, together with the previous evidence of the presence of Egyptian clerics in Tarragona, we can suppose there was a relatively intense and fluid exchange between one extreme of the Mediterranean and another, and most of all, contact with the Coptic world from very early times. I do not believe that Terrassa directly copy the prototype of coptic paintings, but the programmer or designer of Sant Miquel clearly possessed an awareness of iconographic traditions of Early-Byzantine period, particularly the Coptic church. We don't know if the connection was direct, but these theophanies are part of a religious and artistic network, larger than the renderings themselves.

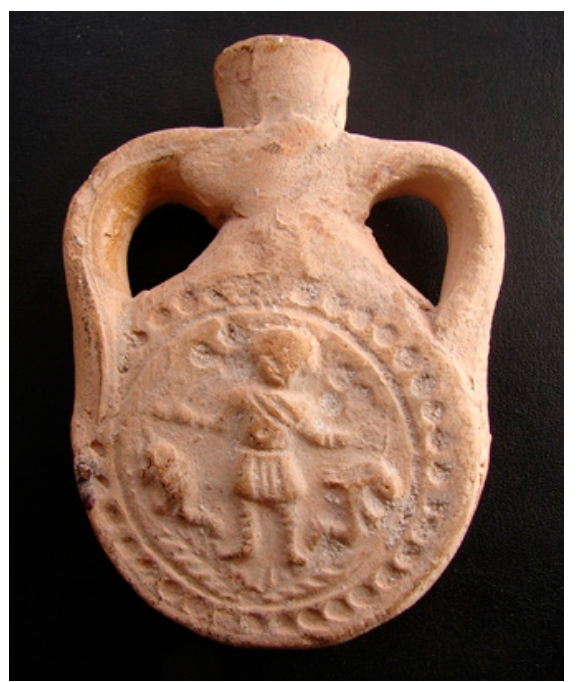

Figure 29. Pilgrimage flask with the image of Saint Menas. (C) Tarragona, Museu Bíblic (with kind permission).

\section{Chronology}

The new historical-artistic context proposed for the paintings of Sant Miquel de Terrassa transforms this ensemble into a missing link in the reception of the repertories and motifs of the Mediterranean East in the Iberian Peninsula. The knowledge of holy places in Egypt and the receiving of iconographies and liturgies, as well as the fascination over Byzantium, created a favorable framework for cultural and artistic transference.

In this respect, new archaeological, technical and epigraphic data on the complex of Egara obtained within the Director Plan (1995-2009) seems to confirm an early date around the 6th century.

\subsection{Archaeological Verdict}

As we have seen at the beginning of this article, the archaeological excavations at the See of Egara performed as part of the Director Plan have allowed for us to set a definitive chronological sequence for the episcopal complex. Having surpassed the old historiographic debates on the dating of the complex, the historiography unanimously places the building of the architectural complex at the moment of the episcopal designation (c. 450-465). During the bishopric of Irineus, construction began on a grand episcopal complex, formed by the Cathedral of Santa Maria (with a basilical plan and three naves), the funerary building of Sant Miquel and the parish of Sant Pere. Construction ended well into the 6th century, with the building of the churches of Sant Miquel, Sant Pere and the new apse for the Cathedral of Santa Maria. In the year 1980, architect Ambrós i Monsonís (1980, 1982a, 1982b) carried out work to consolidate the roof of the apse of Santa Maria and found a great number of amphorae embedded in the structure, from which he extracted one specimen. A study by S. Keay allowed for the setting of a date for these specimens, of the type Keay LXIa, that came from Northern Africa, to have a chronology of 550-700. With all of this data, the archaeological team concluded that the construction of the existing apse of Santa Maria was produced in the 6th century. 


\subsection{The Verdict of the Restorers}

The proceedings and analyses of the different teams who have worked at the complex have not only allowed for us to know the pictorial technique, but they have also provided new arguments for the dating of wall paintings (Figure 30). In the first place, according to the works in restoration of the paintings undertaken in the years 2001 and 2002, the pictorial technique utilized at Sant Miquel is a specific version of fresco painting, which consists of applying a very thick and irregular arriccio layer on the whole surface of the cupola. After a short time, an intonaco layer was applied, over which the decoration was applied to the fresco. ${ }^{31}$ In the second place, according to the diagnosis of materials carried out by the restorers, there does not exist any kind of layer between the arriccio and the stone, in such a way that the arriccio penetrated the joints of the stones that compose the wall of the apse. This led them to believe that the construction of the cupola of Sant Miquel and the application of the arriccio most probably were from the same moment (ARCOR 2002, p. 22).

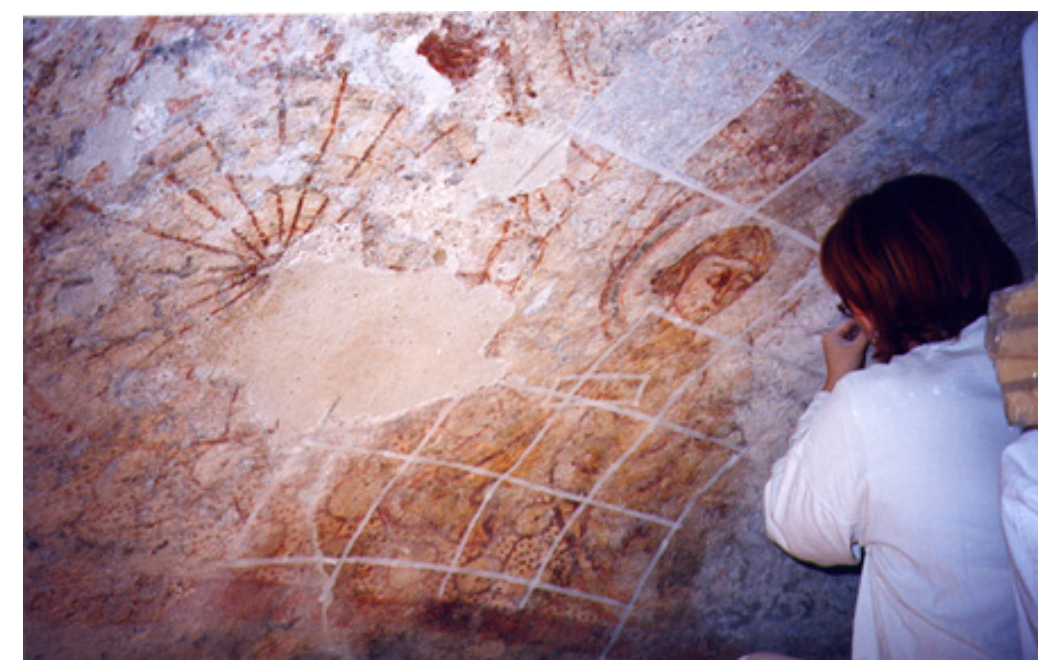

Figure 30. Sant Miquel de Terrassa. Restoration of the paintings undertaken in the years 2001 and 2002. (C) ARCOR.

The hypothesis of contemporaneity between the paintings and their architectural support was supported by a second team of restorers. In 2004 they drafted a restoration project for the wall paintings of Santa Maria, which historiography unanimously dates to the same chronological moment and the paintings of Sant Miquel. ${ }^{32}$ I believe that the study undertaken by Rudi Ranesi, Lourdes Domedel, and Conxa Armengol is quite suggestive in this respect:

Two very similar types of mortar have been detected between them: the one used for joints and the other from the intonaco layer ( ... ). The composition of the lime studied under the electron microscope has defined the type of material: calcium carbonate ( ... ). The compositional uniformity of the materials confirms that the different strata correspond to the same time period and are contemporary to the construction of the cupola. (Ranesi et al. 2004, p. 30)

The diagnosis of the uniformity of the mortars used in the paintings of Santa Maria was confirmed in the analysis performed by Lluís Vilaseca and Núria Guash as part of the same project (Figure 31), whose conclusions do not harbor any doubts:

31 According to the restorers, this technique is different from the traditional Roman fresco technique described by Vitruvius and is also different from Catalonian Roman frescoes, which have a finer arriccio and a regular thickness in the layer covering it. See (ARCOR 2001, 2002).

32 See (Ranesi et al. 2004). The paintings of Santa Maria were finally restored in the years 2008 and 2009 by the TRACER company (TRACER 2009, p. 42). 
In light of the obtained data, it is perfectly possible to contextualize the time periods of the paintings to be contemporary with the construction of the cupola. (Vilaseca and Guasch 2004, p. 46)

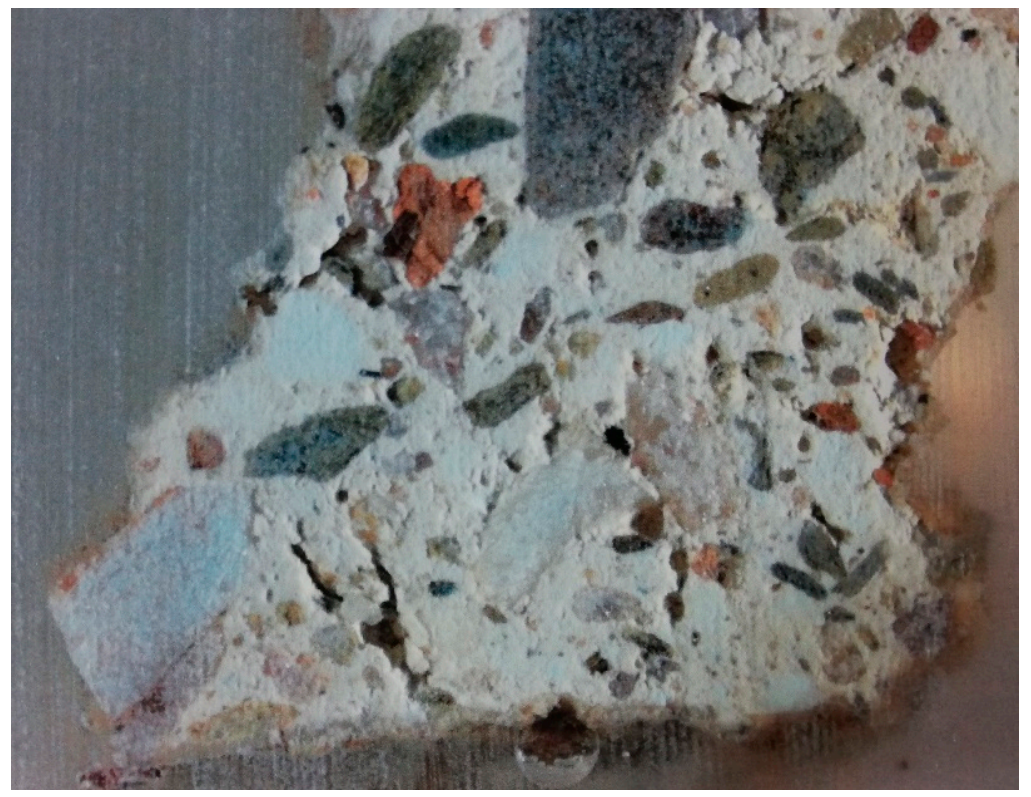

Figure 31. Diagnosis of the mortars used in the paintings of Santa Maria de Terrassa. (C) Museu de Terrassa (with kind permission).

Although the physical and compositional similarities between the mortar from the joints and the mortar of the layers in preparation for the paint is not an ultimate argument, it is a very reliable sign to be able to set the chronology of the paintings to the moment of the construction of the apses, where the architectures dates it to the 6th century.

We have another factor supporting this hypothesis: during the works in excavation, remnants of paint drip spatter in a reddish color, very similar to the pictorial gamma of the apse, were found beneath the level of the original pavement work. If this spatter were to be from cleaning the actual brushes, we could think that the paintings were created before the original building was paved (Garcia Llinares et al. 2009, p. 143).

\subsection{The Verdict of the Epigraphists}

Conversely, as we have already seen, within the framework of the works in preservation of the Church of Sant Miquel performed in the years 2001-2002 new inscriptions appeared. Diana Gorostidi (Universidad Rovira i Virgili, ICAC) and Jordi López (Catalán Institute of Classical Archaeology) determined that the inscriptions follow forms from the paleo-Christian epigraphy of the Visigoth period, and as such seem to confirm the chronology of the 6th century (López Vilar and Gorostidi 2015a). ${ }^{33}$

\section{Conclusions}

Since their discovery near the end of the 19th century, the wall paintings of Sant Miquel de Terrassa have been at the forefront of an intense debate centered around defining their iconography and dating. In the first place, regarding the iconographic theme, although the primary source for the configuration of the paintings of Sant Miquel is the Ascension of Christ, we find other motifs that come from the Vision of Ezekiel (throne, cartwheels) that endowed the image with a whole new semantic meaning. The result is a synoptic theophany in which the patrons wished to underscore the divinity of Christ.

In this sense, the presence of the aforementioned motifs, as well as the gesticulation of the Apostles, demonstrates knowledge of Eastern models, and specifically the theophanies predominant in Coptic art from the 6th-7th centuries. In support of this hypothesis, it is well worth underscoring 
the exceptionality of the gestures of the Apostles, which probably have their origins in a possible form of a chant or repertoire specific to Eastern liturgies.

In the framework of the heretical conflicts that shook the Mediterranean East in the 4 th-5th centuries, the Orthodox Church created certain dogmatic images that it held in evidence before the faithful, with the conclusions derived from the great ecumenical councils-Nicea (325), Ephesus (431), and Chalcedon (451) - regarding the divinity of Christ and the divine motherhood of Mary. We have several ancient examples of this type of images, all composed in the same manner and with a chronology situating them in the 6th century. In a context in which controversy was alive in Visigothic Hispania, it is logical to think that they would recur to iconography from the East as a contribution to the controversy by the Catholic Church.

One very important avenue of thought to consider when pondering the reception of these images by the Eastern Hispanogoths is that of relationships with the Coptic world. Be it by means of travel to holy places or the arrival of communities from Egypt, what is true is that the province of Tarragona could have played a determining role as a center of reception and diffusion of influences; a veritable bridge between the Western and Eastern Mediterranean. The religious and cultural relationships with the Byzantine East explain not only the rise in travel but also the circulation of iconographic objects and models.

Conversely, I believe that the holistic view we have undertaken situates the paintings in a new historical-artistic framework: that of the Mediterranean within the framework of Justinian's renovation imperi (6th century). With this idea in mind, the technical data obtained from the archaeological interventions, and above all, from the restorative works carried out in Terrassa, seem to confirm this new dating for the paintings. The technical reports point to a contemporaneity between the paintings and their architectural support, to mean that they were created at the moment of supreme splendor of the Episcopal See of Egara, circa the 6th century. We cannot forget that soon after, in the year 615, the Episcopal See of Egara was host to an important provincial synod, before its definitive dissolution by the Muslim invasion (711). This seems to be a favorable framework for the appearance of a complex and a monumental pictorial decoration such as that in Terrassa: a missing link for the reception of painting from the Mediterranean East.

The Muslim invasions of the Iberian Peninsula marked the end of the era of the greatest splendor of the monumental complex and the end of the Bishopric of Egara. After the conquest of Barcelona in the year 801 by the Franks, the country's stability allowed for certain episcopal sees to be reinstituted (Soler i Jimenez 2003, pp. 81-90), with the exception of Egara and Empúries. For this reason, I find it difficult to accept that a pictorial decoration of such monumentality and dogmatic content would have been carried out in the Carolingian Period when Egara was no longer an episcopal see and the complex had begun its spatial and architectural decline.

The see of Egara is the only complex among the ancient episcopal sees (5th-8th centuries) still preserved in the West having vestiges of the pictorial decoration in the apses of its three churches. Other episcopal complexes such as those in Valencia, Barcelona, and Mérida (Spain), Aosta (Italy), Geneva (Switzerland), Porec (Croatia), or Grenoble (France), have preserved important architectural vestiges, but not mural paintings. This fact transforms the ensemble at Terrassa into an "hapax" within the study of Western Christian art.

Funding: This research received no external funding.

Acknowledgments: This contribution is the result of a long period of research that has involved many people and institutions, to all of whom I am immensely grateful. I am indebted to Manuel Castiñeiras for his help and suggestions during the preparation of this text. I would also like to express my most sincere thanks to Mary Kupellian (Helwan University, Cairo); Domènec Ferran and Antonio Moro, respectively Director and Archeologist at the Museum of Terrassa; Maricarmen Gómez Muntané (Universitat Autònoma de Barcelona); John McNeill (University of Oxford); Juan Signes (Universidad de Valladolid); Antonio Pizá (Foundation for Iberian Music); Rafael Pérez Arroyo (Universidad Rey Juan Carlos); David Abadías and Gemma Garcia, respectively Dean and Lecturer of the Faculty Antoni Gaudí; Andreu Muñoz (Museu Bíblic de Tarragona); Arturo Palomares (Ajuntament de Terrassa); Antonio Iacobini (Università di Roma La Sapienza); Magdalena Kuhn and Laura de Castellet. 
Conflicts of Interest: The author declares no conflict of interest.

\section{References}

Ainaud de Lasarte, Joan. 1959. Terrassa. Les églises d’Égara. In Congrès Archéologique de France "Catalogne", CXVIIe Session. Paris: Société Française d'Archéologie, pp. 189-98.

Ainaud de Lasarte, Joan. 1976. Los templos visigótico-románicos de Tarrasa. Madrid: Editora Nacional.

Ambrós i Monsonís, Jordi. 1980. Les obres de restauració de l'antiga seu del bisbat d'Ėgara. Quaderns d'Estudis Medievals 2: 101-12.

Ambrós i Monsonís, Jordi. 1982a. Obres de restauració dels edificis de la seu de l'antic bisbat d’Ègara. Baptisteri de Sant Miquel. Quaderns d'Estudis Medievals 8: 491-507.

Ambrós i Monsonís, Jordi. 1982b. Obres de restauració dels edificis de la seu de l'antic bisbat d'Ègara. Església de Santa Maria. Quaderns d'Estudis Medievals 10: 583-606.

Amengual i Batlle, Josep. 2013. Tarragona, Cartagena, Elx i Toledo. Metropolitans i vicaris papals en el segle VI. Revista Catalana de Teologia 38: 547-90.

Anderson, William. 2007. Menas Flasks in the West. Pilgrimage and Trade at the End of Antiquity. Ancient West $\mathcal{E}$ East 6: 221-43.

ARCOR. 2001. Sant Miquel de Terrassa. Documentació de l'obra i de la restauració, juny-juliol 2001. Terrassa: Arcor. Taller. Estudi. Conservació i Restauració de Pintura.

ARCOR. 2002. Sant Miquel de Terrassa. Documentació de la restauració d'octubre 2001 a març 2002 i noves aportacions a la documentació de l'obra. Terrassa: Arcor. Taller. Estudi. Conservació i Restauració de Pintura.

Arias Abellan, Carmen. 2000. Itinerarios Latinos a Jerusalén y al Oriente Cristiano. Sevilla: Universidad de Sevilla.

Bangert, Susanne. 2006. Menas ampullae, a case study of long-distance contacts. Reading Medieval Studies XXXII: 27-33.

Bango Torviso, Isidro. 1997. La vieja liturgia hispana y la interpretación funcional del templo prerrománico. In VII Semana de Estudios Medievales (Nájera, 29 de julio al 2 de agosto de 1996). Edited by José Ignacio de la Iglesia Duarte. Nájera: Instituto de Estudios Riojanos, pp. 61-120.

Barral i Altet, Xavier. 1981. L'art pre-romànic a Catalunya. Segles IX-X. Barcelona: Edicions 62.

Bäumer, Suitbert. 1905. Geschichte des Breviers, French ed. Freiburg im Breisgau and Paris: Herder. First published 1895.

Belting-Ihm, Christa. 1960. Die Programme der christlichen Apsismalerei vom 4. Jahrhundert bis zur Mitte des 8. Jahrhunderts. Wiesbaden: Forschungen zur Kunstgeschichte und christlichen Archäologie, pp. 95-112.

Belting-Ihm, Christa. 1989. Theophanic Images of Divine Majesty in Early Medieval Italian Church Decoration. In Italian Church decoration of the Middle Ages and Early Renaissance. Functions, Forms and Regional Tradition. Edited by William Tronzo. Bologna: Nuova Alfa, pp. 43-59.

Bertrán de Heredia, Júlia. 2019. La Barcelona visigoda: un puente entre dos mundos. La basílica dels Sants màrtirs Just $i$ Pastor: de la ciudad romana a la ciudad altomedieval. Barcelona: Ateneu Universitari Sant Pacià.

Blázquez Martínez, José María. 1967. Posible origen africano del cristianismo español. Archivo Español de Arqueología 40: 30-50.

Brubaker, Leslie. 2009. Gesture in Byzantium. In The Politics of Gesture: Historical Perspectives. Edited by Michael Braddick. Oxford: Oxford University Press, pp. 36-56.

Castellano i Tresserra, Anna, Imma Vilamala, and Antoni González Moreno-Navarro. 1993. Les restauracions de les esglésies de Sant Pere de Terrassa. L'actuació del Servei de Catalogació i Conservació de Monuments de la Diputació de Barcelona, 1915-1951, Monografies 3. Barcelona: Diputació de Barcelona.

Christe, Yves. 1969. Les grands portails romans. Études sur l'iconologie des théophanies romanes. Genéve: Études et documents públiés par les Instituts d'Histoire de la Faculté de Lettres de l’Université de Genève, 7.

Cirici i Pellicer, Alexandre. 1945. Contribución al estudio de las Iglesias de Terrassa. Ampurias VII-VIII: 215-32.

Clédat, Jean. 1904. Le monastère et la nécropole de Baouît, Tome I, Fascicules 1-2. Le Caire: Mémories publiés par les membres de l'Institut Français d'Archéologie Orientale du Caire, XII.

Cook, Walter William Spencer, and José Ricart Gudiol. 1950. Ars Hispaniae I: Pintura e Imageneria Románicas. Madrid: Plus Ultra.

Davis, Stephen J. 2001. The Cult of Saint Thecla: A tradition of Women's Piety in Late Antiquity. Oxford: Oxford University Press. 
De Santiago Fernández, Javier. 2009. El hábito epigráfico en la Hispania visigoda. In VIII Jornadas Científicas Sobre Documentación de la Hispania Altomedieval (siglos VI-IX). Edited by Nicolás Ávila Seoane, Manuel Joaquín Salamanca López and Leonor Zozaya Montes. Madrid: Dpto. de Ciencias y Técnicas Historiográficas, Universidad Complutense de Madrid, pp. 291-344.

Del Amo Guinovart, $\mathrm{M}^{\mathrm{a}}$ Dolores. 1997. Tecla et Theclae. De la santa de Iconio a la beata tarraconense. In El temps sota control. Homenatge a F. Xavier Ricomá Vendrell. Tarragona: Diputació de Tarragona, pp. 123-29.

Del Amo Guinovart, $\mathrm{M}^{\mathrm{a}}$ Dolores. 2001. Obispos y eclesiásticos de Tarraco desde inicios del Cristianismo a la invasión sarracena del 711 d.C. Butlletí Arqueològic 23: 259-80.

Dewald, Ernest. 1915. The Iconography of the Ascension. American Journal of Archaeology 19: 277-319. [CrossRef]

Díaz y Díaz, Manuel Cecilio. 1967. Entorno a los orígenes del Cristianismo hispánico. In Las raíces de España. Edited by José Manuel Gómez Tabanera. Madrid: Instituto Español de Antropología, pp. 423-43.

Drescher, James. 1946. Apa Mêna: A Selection of Coptic Texts Relating to St. Menas. Cairo: Publications de la Société d'archéologie copte.

Escribano Paño, María Victoria. 1998. Zaragoza en la Antigüedad Tardía (285-714). Historia de Zaragoza 3. Zaragoza: Ayuntamiento. Servicio de Cultura.

Ferotin, Marius, ed. 1904. Le Liber Ordinum en usage dans l'Église wisigothique et mozárabe d'Espagne du cinquième au onzième siècle. Paris: Firmin-Didot.

Ferran, Domènec. 2009. Ecclesiae egarenses. Les esglésies de Sant Pere de Terrassa. Barcelona: Lunwerg.

Ferran, Domènec. 2015. Les pintures murals de l'absis de Sant Miquel. Anàlisi iconogràfica. Terme 30: 118-25.

Fitzerald Johnson, Scott. 2006. The Life and Miracles of Thecla. A Literary Study. Cambridge: Harvard University Press.

Flórez, Enrique. 1754. España Sagrada, Teatro geográfico-histórico de la Iglesia de España. Tomo III. Madrid: En la oficina de Antonio Marín.

Flórez, Enrique. 1770. España Sagrada, Teatro geográfico-histórico de la Iglesia de España. Tomo XXV. Madrid: En la oficina de Antonio Marín.

Garcia Llinares, Gemma, Antonio Moro, and Francesc Tuset. 2009. La Seu Episcopal d'Égara. Arqueologia d'un conjunt cristià del segle IV al segle IX. Serie Documenta 8; Tarragona: Institut Català d'Arqueologia Clàssica.

Garcia Llinares, Gemma, Antonio Moro, and Francesc Tuset. 2015. L'edifici funerari de Sant Miquel. Terme 30: 75-100.

Gomá, Isidro. 1907. Fundamentos históricos del culto a S. Pablo y Sta. Tecla. Boletín Arquológico de la Real Sociedad Arqueológica Tarraconense VII: 669-94.

Grabar, André. 1945. Une fresque visigothique et l'iconographie du silence. Cahiers Arqueologiques 1: 124-28.

Grabar, André. 1958. Ampoules de Terre sainte (Monza-Bobbio). Paris: Klincksieck.

Grabar, André. 1970. Deux portails sculptés paléochrétiens en Egipte et d'Asie Mineure, et les portails romans. Cahiers Archéologiques XX: 15-28.

Gros i Pujol, Miquel dels Sants. 1992. Les Wisigoths et les liturgies occidentales. In L'Europe héritiére de l'Espagne wisigothique—Rencontres de la Casa de Velázquez. Edited by Jacques Fontaine. Madrid: Casa de Velázquez, pp. 125-35.

Grossmann, Peter. 1989. Abu Mina I: Die Gruftkirche und die Gruft. Mainz am Rhein: P. von Zabern.

Grossmann, Peter. 1998. The Pilgrimage Center of Abu Mina. In Pilgrimage and Holy Space in Late Antique Egypt. Edited by David Frankfurter. Leiden: Brill, pp. 291-302.

Guardia, Milagros. 1992. La pintura mural pre-romànica de les esglésies de Sant Pere de Terrassa. Noves propostes d'estudi. In Actes del I Simposi Internacional sobre les Esglésies de Sant Pere de Terrassa (20-22 de novembre de 1991). Terrassa: Centre d'Estudis Històrics-Arxiu Històric Comarcal, pp. 153-60.

Iacobini, Antonio. 2000. Visione dipinte. Immagini della contemplazione negli affreschi di Bawit. Roma: Viella.

Keay, Simon. 1996. Tarraco in Late Antiquity. In Towns in transition. Urban Evolution in Late Antiquity and Early Middle Ages. Edited by Neil Christie and Simon T. Loseby. Aldershot: Scolar, pp. 18-43.

Kuhn, Charles Louis. 1928. Notes on Some Spanish Frescoes. Art Studies 6: 123-34.

Kuhn, Charles Louis. 1930. Romanesque Mural Painting of Catalonia. Cambridge: Harvard University Press.

Kuhn, Magdalena. 2014. Coptic music culture. Tradition, structure, and variation. In Coptic Civilization. Two Thousand Years of Christianity in Egypt. Edited by Gawdat Gabra. Cairo-New York: The American University in Cairo Press, pp. 67-78.

López Vilar, Jordi, and Diana Gorostidi. 2015a. Les inscripcions visigodes de l'absis de Sant Miquel. Terme 30: 101-109. 
López Vilar, Jordi, and Diana Gorostidi. 2015b. Noves consideracions sobre la inscripció tarraconense de la beata Thecla (segle V). Pyrenae 46: 131-46.

Mac Coull, Leslie. S. B. 1986. Redating the Inscription of El-Moallaqa. Zeitschrift für Papyrologie und Epigraphik 64: 230-34.

Maguire, Henry. 1977. The Depiction of Sorrow in Middle Byzantine Art. Dumbarton Oaks Papers 3: 123-74. [CrossRef]

Mancho, Carles. 2012. La peinture murale de haut Moyen Âge en Catalogne (IX-X siècle). Turnhout: Brepols.

Mancho, Carles. 2018. La decorazione delle chiese di Sant Pere de Terrassa, esempio dell'uso politico di monumenti tardo-antichi nell'altomedioevo. Hortus Artium Medievalium 24: 152-61. [CrossRef]

Maniche, Lisa. 1991. Music and Musicians in Ancient Egypt. London: British Museum Press.

Maraval, Pierre. 1982. Égérie. Journal de Voyage. Introduction, Texte Critique, Traduction, Notes, Index et Cartes. Paris: Éditions du Cerf.

Martí i Bonet, Josep Maria. 1992. Els origens del Bisbat d’Égara. In Actes del I Simposi Internacional sobre les Esglésies de Sant Pere de Terrassa (20-22 de novembre de 1991). Terrassa: Centre d'Estudis Històrics-Arxiu Històric Comarcal, pp. 61-71.

Martí i Bonet, Josep Maria. 2004. Barcelona i Égara-Terrassa. In Història primerenca fins l'alta edat Mitjana de les dues Esglésies Diocesanes. Barcelona: Arxiu Diocesà.

Martín-Delgado Sánchez, José Manuel. 2018. El canto litúrgico en la reforma del rito mozárabe de Cisneros: Tradición, pervivencia y restauración. Ph.D. thesis, Universidad de Castilla-la Mancha, Cuenca, Spain.

Migne, Jacques Paul, ed. 1844-1855. Patrologia Latina. París.

Mundó i Marcet, Ascani. 1992. El bisbat d’Égara de l’època tardo-romana a la Carolíngia. In Actes del I Simposi Internacional sobre les Esglésies de Sant Pere de Terrassa (20-22 de novembre de 1991). Terrassa: Centre d'Estudis Històrics-Arxiu Històric Comarcal, pp. 41-49.

Notre messe. 1963. Notre messe selon la liturgie copte dite de Saint Basile le Grand, 3e ed. rev. et corr. sous le Pontificat de S.B. Stéphanos Ier. Le Caire: Editions du Foyer Catholique.

Papaconstantinou, Arieta. 2007. The cult of saints: A haven of continuity in a changing world? In Egypt in the Byzantine World. Edited by en Roger S. Bagnall. Cambridge: Cambridge University Press, pp. 350-67.

Peers, Glenn. 2007. Vision and community among Christians and Muslims: the al-Mu'allaqa lintel and its eight-century context. Arte Medievale 6: 25-46.

Pentcheva, Bissera. 2000. Imagined Images: Vision of Salvation and Intercession in Double-Sided Icon from Poganovo. Dumbarton Oaks Papers 54: 139-53. [CrossRef]

Pijoan, Josep, and Josep Gudiol. 1948. Les pintures murals romàniques de Catalunya. In Monumenta Cataloniae. Barcelona: Alpha, vol. IV.

Pinell, Jordi. 1998. Liturgia Hispánica. Barcelona: Centre de Pastoral Litúrgica.

Presedo Velo, Francisco. 2003. La España Bizantina. Sevilla: Universidad de Sevilla. Secretariado de Publicaciones.

Puig i Cadafalch, Josep. 1931. Les peintures du VI siècle de la cathédrale d'Egara. Comptes rendus des séances de l'Académie des Inscriptions EBelles-Lettres 75: 154-62.

Puig i Cadafalch, Josep. 1932a. Les pintures del segle vi de la catedral d'Egara (Terrassa) a Catalunya. Butlletí dels Museus d'Art de Barcelona vol. II: 97-105.

Puig i Cadafalch, Josep. 1932b. Les pintures del segle vi e de la catedral d'Egara (Terrassa) a Catalunya. Arxiu del Centre Excursionista de Terrassa any XIV, $2^{a} \mathrm{ep} . \mathrm{n}^{\circ} 80$ : 86-91.

Puig i Cadafalch, Josep. 1936. Les pintures del segle vi de la catedral d'Egara (Terrassa). Anuari de l'Institut d'Estudis Catalans VIII: 141-49.

Puig i Cadafalch, Josep. 1948. Noves descobertes a la catedral d’Ègara. Barcelona: Institut d'Estudis Catalans.

Ranesi, Rudi, Lourdes Domedel, and Conxa Armengol. 2004. Projecte de Restauració de les Pintures Murals de Santa Maria de Terrassa. Terrassa.

Rodríguez G. de Ceballos, Alfonso. 1965. El reflejo de la liturgia visigótico-mozárabe en el arte español de los siglos VII al X. Miscelánea Comillas: Revista de Ciencias Humanas y Sociales 21: 293-327.

Roig Buxó, Jordi, Coll Riera, Joan Manuel, and Josep-A. Molina i Vallmitjana. 1995. L'església vella de Sant Menna. Sentmenat del segle $V$ al segle XX. Sentmenat: Ajuntament.

Sacopoulo, Marina. 1957. Le linteau copte dit d'Al-Moallaka. Cahiers Archeologiques 9: 99-115.

Schiller, Gertrud. 1971. Ikonographie der christlichen Kunst. Gutersloh: Gutersloher Verlagshaus Gerd Mohn. 
Schlunk, Helmut. 1945. Relaciones entre la Península Ibérica y Bizancio durante la época visigoda. Archivo Español de Arqueología 18: 177-204.

Schlunk, Helmut. 1964. Byzantinische Bauplastik aus Spanien. Madrider Mitteilungen 5: 234-54.

Schlunk, Helmut. 1971. La iglesia de San Gîao, cerca de Nazaré. Contribución al estudio de la influencia de la liturgia de las iglesias prerrománicas de la península Ibérica. In Actas do II Congresso Nacional de Arqueología. II. Coimbra: Ministério de Educação Nacional, pp. 509-28.

Schmidt, Victor. 1991. Ascensione. In Enciclopedia dell'Arte Medievale. II. Rome: Enciclopedia Italiana, pp. 572-77. Semoglou, Athanasios. 2012. La théophanie de Latôme et les exercices d'interprétations artistiques durant les 'renaissances' byzantines. Les noveuax signifiants de (la vision de) Dieu. Paper presented at Byzantium Renaissances: Dialogue of Cultures, Heritage of Antiqiuty Tradition and Modernity, Warsaw, Poland, 19-21 October 2011; Edited by Michal Janocha, Aleksandra Sulikowska and Irina Tatarova. pp. 231-39.

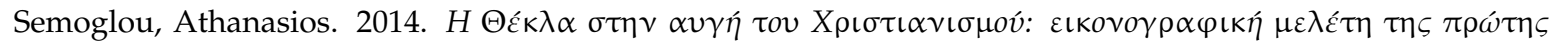

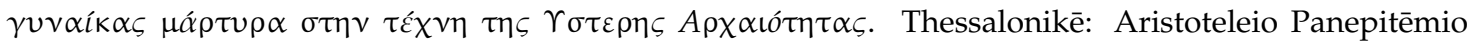
Thessalonikēs, Kentro Vyzantinōn Ereunōn.

Snyder, James. 1967. The Meaning of 'Maiestas Domini' in Hosios David. Byzantion 37: 143-52.

Soler i Jimenez, Joan. 2003. El territori d'Égara, des de la Seu Episcopal fins al Castrum Terracense (segles V-X). Alguns residus antics en la toponímia altmedieval. Terme 18: 59-95.

Soler i Palet, Josep. 1928. Egara-Terrassa. Terrassa: Tallers Gràfics Joan Morral.

Thompson, Edward Arthur. 2014. Los godos en España. Madrid: Alianza Editorial. First published 1971.

TRACER. 2009. Memoria Final de Restauración de las Pinturas Murales del ábside de la Iglesia de Santa María de Terrassa (Barcelona). Madrid: Diputación Foral de Álava.

Vallejo Girvés, Margarita. 2003. Los exilios de católicos y arrianos bajo Leogivildo y Recaredo. Hispania Sacra 55: 35-48. [CrossRef]

Vallejo Girvés, Margarita. 2004. El exilio bizantino: Hispania y el Mediterráneo occidental (siglos V-VII). In Bizancio y la Península ibérica. De la antigüedad tardía a la Edad Moderna. Edited by Inmaculada Pérez Martín and Pedro Bádenas de la Peña. Madrid: CSIC, pp. 117-54.

Vallejo Girvés, Margarita. 2012. Hispania y Bizancio. Una relación desconocida. Madrid: Akal.

Van der Meer, Frédéric. 1938. Maiestas Domini: Theophanies de l'Apocalypse dans L'Art Chrétien-Etude sur les Origines d'una iconographie spéciale du Christ. Paris and Roma: Citta del Vaticano, Roma, Pontificio istituto di archeologia cristiana.

Vilaseca, Lluís, and Núria Guasch. 2004. Diagnosi de materials de les pintures murals de la cúpula de l'església de Santa Maria de Terrassa. In Projecte de Restauració de les Pintures Murals de Santa Maria de Terrassa. Edited by Rudi Ranesi, Domedel Lourdes and Armengol Conxa. Terrassa.

Vinulović, Ljubica. 2018. The Miracle of Latomos: From the Apse of the Hosios David to the Icon from Poganovo. In The Migration of the Idea of Salvation, Migrations in Visual Art. Edited by Jelena Erdeljan, Martin Germ, Ivana Prijatelj Pavičić and Marina Vicelja Matijašić. Belgrade: University of Belgrade, pp. 175-86.

Vives, José. 1963. Concilios Visigóticos e Hispano-Romanos. Madrid: Consejo Superior de Investigaciones Científicas, Instituto Enrique Flórez.

Vizcaíno Sánchez, Jaime. 2009. La presencia bizantina en Hispania (siglos VI-VII). La documentación arqueológica. Murcia: Universidad de Murcia.

Vizcaíno Sánchez, Jaime. 2013. Hispania y Oriente durante el período de ocupación bizantina (siglos VI-VII). La documentación arqueológica. In El Oriente griego en la Península Ibérica. Epigrafía e Historia. Edited by María Paz de la Hoz and Gloria Mora. Madrid: Real Academia de la Historia, pp. 281-305.

Weitzmann, Kurt. 1976. The Monastery of Saint Catherine at Mount Sinai. The Icons I: From de the sixth to the tenth Century. Princeton: Princeton University Press.

Wilkinson, John. 1971. Egeria's Travels. London: SPCK.

(C) 2019 by the author. Licensee MDPI, Basel, Switzerland. This article is an open access article distributed under the terms and conditions of the Creative Commons Attribution (CC BY) license (http://creativecommons.org/licenses/by/4.0/). 